\title{
ARCHEOLOGIA KLASYCZNA NA UNIWERSYTECIE W POZNANIU I KONTEKSTY JEJ POWOLYWANIA*
}

\author{
CLASSICAL ARCHAEOLOGY AT THE UNIVERSITY \\ IN POZNAŃ AND CIRCUMSTANCES OF ITS ESTABLISHING
}

\author{
Ewa Bugaj \\ Instytut Prahistorii, Uniwersytet im. Adama Mickiewicza \\ ul. Św. Marcin 78, 61-809 Poznań, Poland
}

\begin{abstract}
The article presents the history of Classical Archaeology as a research and study area in Poznań, from the perspective of the times in which it was created and developed. The author of the text also outlines scientific achievements of Poznań university centre in the field. The subject was established already in 1919 with the creation of the University of Poznan itself, and it grew steadily in the interwar period, mainly through the efforts of the only specialist - Mieczysława S. Ruxer, PhD. After World War II, Classical Archaeology had been taught at the University since the resumption of its activities in 1945 until 1969, when it was closed. Archaeologists, however, continued both research and teaching in the area - working in the Institute of History and the Institute of History of Art. Moreover, since 1970 Adam Mickiewicz University in Poznań has had its own archaeological mission excavating the ancient legion camp and the city of Novae (present Bulgaria). After the fall of communism and the political transformation in 1989, endeavours were made to reactivate Classical Archaeology in Poznań. As a result, it was re-created in 1999, being a part of the Archaeology subject at the Institute of Prehistory, as a specialisation of Archaeology of the Mediterranean. In 2004 it was renamed and since then there has been the specialisation of Oriental and Ancient Archaeology, developing at the Institute of Prehistory at Adam Mickiewicz University.
\end{abstract}

Rozwój archeologii klasycznej w formie instytucjonalnej skonsolidował się w Europie w XIX w., kiedy powoływano i rozwijano katedry uniwersyteckie, jak również na terenie przede wszystkim Italii, a później Grecji, instytuty badawcze

\footnotetext{
* Inspiracją do napisania niniejszego tekstu była konferencja jubileuszowa, która odbyła się w dniach 2-3 lipca 2009 r. w Obrzycku, zorganizowana dla uczczenia 90-lecia archeologii uniwersyteckiej w Poznaniu. Wpisywała się ona w obchody takiego samego Jubileuszu Uniwersytetu im. Adama Mickiewicza w Poznaniu.
} 
i szkoły ${ }^{1}$, będące zasadniczo przedstawicielstwami domen narodowych, ale czasami też środowisk międzynarodowych, w ramach których uczeni podejmowali systematyczne prace badawcze, $w$ tym wykopaliskowe na obszarach śródziemnomorskich ${ }^{2}$. W Polsce archeologia klasyczna nie miała szans podobnego zaistnienia i rozwoju z powodów historycznych, gdyż nie mieliśmy wówczas niepodległości, pozostając pod władaniem obcych mocarstw. Nie oznaczało to braku zainteresowania antykiem greckim i rzymskim, który wraz z chrześcijaństwem uważano powszechnie za fundament kultury europejskiej i podstawę europejskiej tożsamości. Nie oznaczało również całkowitego braku rozwoju polskich badań nad antykiem, które kwitły jednak głównie dzięki indywidualnym studiom miłośników starożytności, dzięki podróżnikom i kolekcjonerom, a rozwijane były między innymi także w ramach funkcjonujących towarzystw naukowych, pełniących rolę organizatorów życia naukowego w zaborach ${ }^{3}$.

W Poznaniu momentem przełomowym dla szans na rozwój archeologii klasycznej było jednak dopiero utworzenie w 1919 r. Uniwersytetu, które splotło się z odzyskaniem przez Polskę niepodległości po ponad stu latach niewoli ${ }^{4}$. Wśród licznych

\footnotetext{
${ }^{1}$ Jednym $\mathrm{z}$ najwcześniejszych instytutów naukowych zorganizowanych na potrzeby badań materialnych pozostałości antyku - dzieł sztuki i architektury, czyli, jak to wówczas określano: „zabytków monumentalnych" a nie wyłącznie tekstów, co stanowiło już od dawna powszechny sposób postępowania badawczego na gruncie tzw. studiów klasycznych, był uformowany w Rzymie w latach 1823-1929 Instituto di Corrispondenza Archeologica, aczkolwiek wcześniej funkcjonowała już Rzymska Akademia Papieska, a w jej ramach, od 1821 r., Pontifica Accademia Romana di Archeologia - zob. Bulanda 1947, 8 i Dyson 2006, 30-33.

${ }^{2}$ Dyson 2006, rozdziały 2 i 3.

${ }^{3}$ Dalsze, obszerne informacje na temat zainteresowania antykiem w Polsce, rozwiniętego szczególnie w czasach króla Stanisława Augusta oraz tego, co było na tym polu ich skutkiem w okresie zaborów, znajdują się między innymi w publikacjach A. Abramowicza, a głównie w książce Dzieje zainteresowań starożytniczych w Polsce, cz. 2: Czasy stanistawowskie i ich poktosie (1987) oraz tegoż autora Historia archeologii polskiej: poczatki (1992).

${ }^{4}$ Konkretne zabiegi organizacyjne tworzenia Uniwersytetu w Poznaniu podjęto już w połowie $1918 \mathrm{r}$., gdy trwała jeszcze I wojna światowa. A mianowicie pod przewodnictwem prezesa Poznańskiego Towarzystwa Przyjaciół Nauk, dr. Heliodora Święcickiego, utworzono Komisję Organizacyjną Uniwersytetu Polskiego w Poznaniu, w której skład weszli ponadto: ks. dr Stanisław Kozierowski, dr hab. Michał Sobeski oraz dr hab. Józef Kostrzewski (jej sekretarz). W wyniku intensywnych prac Komisji powołano do życia najpierw Wydział Filozoficzny (utworzony formalnie na podstawie dekretu Komisariatu Naczelnej Rady Ludowej z 30 stycznia 1919 r.; Komisariat NRL z kolei pismem z dnia 31 stycznia 1919 r. zwrócił się do Ministerstwa Wyznań Religijnych i Oświecenia Publicznego w Warszawie z informacją o utworzeniu uczelni). Pierwsze posiedzenie Rady Wydziału Filozoficznego, w skład którego wchodziło 21 katedr, odbyło się 4 kwietnia 1919 r., czyli jeszcze przed oficjalnymi uroczystościami otwarcia Uniwersytetu (Wszechnicy Piastowskiej, jak go pierwotnie nazwano), które odbyły się 7 maja 1919 r. - zob. Czubiński 1972, 64-83; Łukomski 2004a, 30-48 i 2004b, 49-59. Warto zaznaczyć, iż dzień 30 stycznia 1919 r. uznawany jest także za oficjalną datę powstania Katedry Prehistorii w Poznaniu, która weszła w skład wspomnianego Wydziału Filozoficznego - zob. Abramowicz 1991, 106, aczkolwiek w księdze pamiątkowej pod red. A. Wrzoska Uniwersytet Poznański w pierwszych latach swego istnienia...
} 
seminariów, które powstały równocześnie z założeniem Uniwersytetu Poznańskiego, powstało także Seminarium Archeologii Klasycznej ${ }^{5}$. Wszystko wskazuje na to, że były to czasy, w których świadomość wagi wykształcenia klasycznego - przede wszystkim filologicznego, szczególnie na polu nauk humanistycznych - była wielka w środowisku polskich intelektualistów inicjujących placówki uniwersyteckie i w ich ramach funkcjonujące kursy, i wpisywała się bardzo dobrze w tego typu myślenie dominujące $\mathrm{w}$ wielu ośrodkach akademickich Europy. Antyk postrzegany był wówczas jako uprzywilejowany okres w dziejach cywilizacji europejskiej, a literatura cieszyła się autorytetem najistotniejszego składnika kultury. Rozumiano ponadto konieczność utrzymywania łączności całej Europy z jej aksjologicznymi korzeniami, w obrębie których antyk miał miejsce stałe. Potwierdzać to może także przypadek poznański i funkcjonowanie $w$ początkowych latach Uniwersytetu aż trzech Katedr Filologii Klasycznej ${ }^{6}$, co wiązało się z liczbą zatrudnionych w Uniwersytecie profesorów tej dyscypliny. Starano się jednak rozwijać w miarę możliwości wszystkie dyscypliny zajmujące się antykiem, zatem także i archeologię. Powracając więc do interesującego nas tutaj Seminarium Archeologii Klasycznej i jego funkcjonowania, wiemy, iż w pierwszych latach istnienia (1919-1923) opiekę nad nim sprawowali kolejno profesorowie: Jan Sajdak (filolog klasyczny), Józef Kostrzewski (archeolog, głównie pradziejowy) i ks. Szczęsny Dettloff (historyk sztuki). Wszyscy oni, co warto dodać, pomimo innej wiodącej specjalizacji naukowej, w trakcie swych rozległych studiów uniwersyteckich także ukończyli kursy archeologii klasycznej lub historii sztuki starożytnej ${ }^{7}$. Kostrzewski na przykład w ramach seminarium archeologii klasycznej prowadził cykl wykładów dotyczących kultury egejskiej. ${ }^{8}$.

Na marginesie warto dodać, że przed powstaniem Uniwersytetu Poznańskiego, w utworzonej w Poznaniu dzięki zabiegom środowiska niemieckiego w 1903 r. Niemieckiej Akademii Królewskiej (niem. Königliche Akademie zu Posen), uczelni wyższego typu, lecz pozbawionej praw nadawania stopni i dyplomów naukowych ${ }^{9}$, zatem nieliczącej się, na jednym z wydziałów - historyczno-filozoficznym - prowadzono od początku zajęcia z historii sztuki, a wykładowcą był między innymi niejaki Carl Fredrich, nauczyciel gimnazjalny, archeolog klasyczny z wykształcenia.

(Poznań 1924), w spisie zakładów Wydziału Filozoficznego na s. 514-515 pod nr. 5. widnieje Instytut Prehistoryczny i jego charakterystyka wraz z informacją, iż powstał w maju 1919 r. jako „Seminarium Prehistoryczne", później przemianowane na wspomniany Instytut.

${ }^{5}$ Zob. przypis 4 i przytoczona tam księga pamiątkowa Uniwersytet Poznański w pierwszych latach..., 521 oraz Sktad Uniwersytetu w roku akademickim 1919/1920, Poznań 1920, 27.

${ }^{6}$ Czubiński 1972, 201.

${ }^{7}$ Uniwersytet Poznański w pierwszych latach..., por. Jan Sajdak, 402; Józef Kostrzewski, 413 i 414 oraz ks. Szczęsny Dettloff, 476; Kaczmarek 1996, 111 oraz 117.

${ }^{8}$ Zob. Spis wykładów. Trimestr trzeci (od 1. maja do 17. lipca 1921 r.), 17.

${ }^{9}$ Grot 1972, 53. 
C. Fredrich $\mathrm{w}$ ramach wykładów $\mathrm{z}$ historii sztuki prowadził zajęcia $\mathrm{z}$ archeologii klasycznej, zajmując się przede wszystkim sztuką antycznej Grecji. Zajęcia owe trwały do 1910 r., kiedy C. Fredricha przeniesiono do gimnazjum w Kostrzynie. Później ich w Akademii nie kontynuowano ${ }^{10}$.

Powracając do Uniwersytetu Poznańskiego i kolejnych etapów konstytuowania się w nim archeologii klasycznej, jako kluczową wskazać należy datę 30 kwietnia 1923 r., kiedy to opiekę nad Seminarium Archeologii Klasycznej objęła wykładająca tę dyscyplinę nauki dr Mieczysława Sabina Ruxerówna ${ }^{11}$. Przybyła ona do Poznania z Krakowa, gdzie studiowała w Uniwersytecie Jagiellońskim, między innymi pod okiem profesora Piotra Bieńkowskiego (1865-1925), twórcy pierwszej na ziemiach polskich katedry archeologii klasycznej, utworzonej w 1897 r. i funkcjonującej właśnie $\mathrm{w}$ tym mieście ${ }^{12}$. Tam też doktoryzowała się i przez jakiś czas pracowała. W Poznaniu, w którym już rok wcześniej prowadziła zajęcia zlecone, M.S. Ruxerówna otrzymała stanowisko zastępcy profesora i zajęła się organizowaniem rzeczywistych podstaw archeologii klasycznej jako specjalności uniwersyteckiej, rozwijającej się zarówno na podstawie badań naukowych, jak i systematycznych zajęć dydaktycznych. Podjęła również trud utworzenia oddzielnego Zakładu. Seminarium posiadało początkowo, tj. do 1924 r., kiedy mamy na ten temat pierwszą wzmiankę, skromną bibliotekę złożoną z 307 tomów, w tym 6 serii czasopism, zbiór 2000 przeźroczy, zbiór fotografii i rycin liczący 300 sztuk oraz 2 odlewy gipsowe. Inwentarz meblowy Seminarium składał się z biurka, stołu, 12 krzeseł, szafy na książki, półek i 2 pudeł drewnianych na katalogi kartkowe. Zbiory te ulokowano w pokoju na półpięterku w byłym Zamku cesarskim ${ }^{13}$, zaadaptowanym częściowo na potrzeby utworzonego Uniwersytetu na jego potrzeby i przemianowanym na Collegium Maius. Tam odbywały się też ćwiczenia. Pozostałe sprzęty Seminarium znajdowały się w głównym budynku Uniwersytetu, którym stał się gmach byłej Akademii Królewskiej, nazywany Collegium Minus ${ }^{14}$. Zbiory Seminarium Archeologii Klasycznej, a szczególnie bibliotekę oraz małe muzeum seminaryjne stale powiększano, o czym świadczą dobitnie kolejne wzmianki archiwalne dotyczące Uniwersytetu, opublikowane w 1925 r., na które powołuje się w swej książce, zbierająca skrupulatnie wszystkie dane na temat organizacji poznańskiej archeologii, Jarmila E. Kaczmarek ${ }^{15}$.

\footnotetext{
${ }^{10}$ Kaczmarek 1996, 82.

${ }^{11}$ Uniwersytet Poznański w pierwszych latach..., 521; Archiwum UAM, Akta Mieczysława Sabina Ruxerówna (dalej: AMSR), sygn. 15-611-26 i sygn. 153-123.

${ }^{12}$ Zob. opracowanie zbiorowe pod red. J. Śliwy Archeologia Śródziemnomorska w Uniwersytecie Jagiellońskim 1897-1997, Kraków 1998, 15-34.

${ }^{13}$ Uniwersytet Poznański w pierwszych latach..., 521, 522.

${ }^{14}$ Łukomski 2004a, 39.

${ }^{15}$ Kaczmarek 1996, 117.
} 
Seminarium w latach przedwojennych funkcjonowało jako kurs poboczny, a Katedra i Zakład Archeologii Klasycznej jako pomocnicze (nadzwyczajne) w ramach Wydziału Humanistycznego, który powstał po reorganizacji Wydziału Filozoficznego w roku $1925^{16}$. Początkowo dr M.S. Ruxerówna w „Kronikach Uniwersytetu Poznańskiego" wymieniana jest jako kierownik Seminarium na stanowisku zastępcy profesora, na którym pozostawała zresztą aż do wojny - ale od roku akademickiego 1926/27 już tylko jako zastępca kierownika, którym formalnie był samodzielny pracownik nauki, dyrektor Katedry zwyczajnej i Instytutu Prehistorycznego, jeden z twórców Uniwersytetu, prof. Józef Kostrzewski ${ }^{17}$. Nazwisko J. Kostrzewskiego, jako kierownika Seminarium Archeologii Klasycznej, jednak nie było umieszczane w „Kronikach Uniwersytetu Poznań-

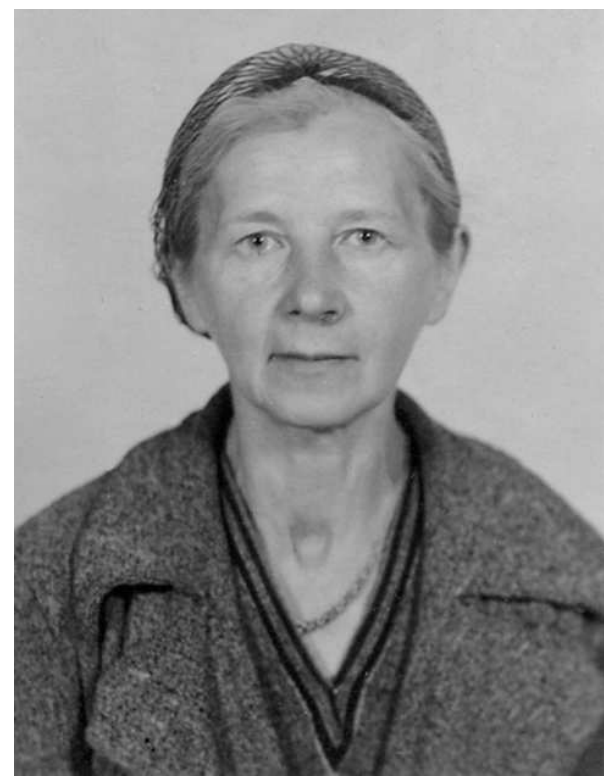

Ryc. 1. Mieczysława Sabina Ruxerówna, lata 30. (?) XX w. Zdjęcie z Archiwum UAM, Akta M.S. Ruxer, sygn. 82-385

Fig. 1. Mieczysława Sabina Ruxer, 1930s (?). The photo from the AMU Archive, Personal dossier of M.S. Ruxer, reference No. 82-385 skiego" lub w publikowanych równolegle dla poszczególnych lat akademickich kolejnych seriach informacyjnych (sprawozdawczych), tj. w „Spisach Wykładów”, jak również w „Składzie Uniwersytetu” oraz w wymienianych tam Zakładach Naukowych przy poszczególnych wydziałach, figurowała z zasady tylko dr M.S. Ruxerówna. Niemniej można zwrócić uwagę na pewną niekonsekwencję w opisach pomiędzy „Kronikami Uniwersytetu” a „Składem”, z czasem połączonym ze „Spisem Wykładów”. Mianowicie w owym „Składzie Uniwersytetu”, przy figurującym w ramach Wydziału Humanistycznego i jego Zakładach Naukowych Seminarium Archeologii Klasycznej pojawia się nieodmiennie zast. prof. dr Mieczysława

\footnotetext{
${ }^{16}$ Czubiński 1972, s. 200, 201.

${ }^{17}$ Zob. seria wydawnictw źródłowych Kronika Uniwersytetu Poznańskiego za rok szkolny... i wzmianki na temat Seminarium Archeologii Klasycznej stosownie w latach: 1923/24, 50; 1924/25, 40; $1925 / 26,35 ; 1926 / 27,53 ; 1927 / 28,52,53 ; 1928 / 29$, 59; za lata 1929/30 i 1930/31, 73; lata 1931/32 i 1932/33 - brak sprawozdań; 1933/34, 157; 1934/35 i następne lata akademickie do wybuchu II wojny światowej - brak sprawozdań indywidualnych z działalności Seminarium w Kronice..., natomiast od roku 1930/31 wymieniane są z kolei w serii Uniwersytet Poznański. Spis Wykładów wszystkie zajęcia prowadzone z zakresu archeologii klasycznej.
} 


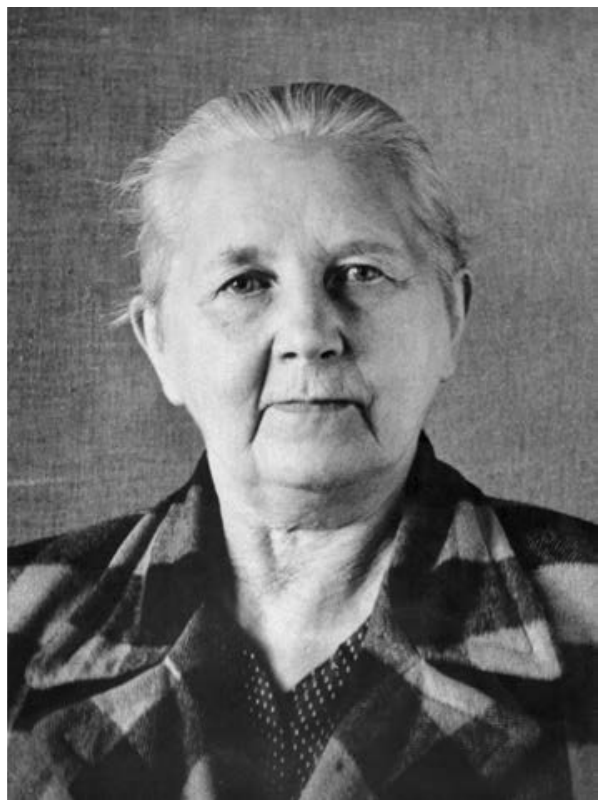

Ryc. 2. Mieczysława Sabina Ruxerówna (18911957). Zdjęcie $\mathrm{z}$ archiwum Instytutu Historii Sztuki UAM

Fig. 2. Mieczysława Sabina Ruxer (1891-1957). The photo from the archive of the Institute of History of Art AMU
S. Ruxerówna wyłącznie jako kierownik $^{18}$. Zmienia się to $\mathrm{w}$ opisach wspomnianych publikacji jedynie $\mathrm{w}$ roku akademickim $1934 / 35^{19}$ i $1935 / 36^{20}$ (za rok 1936/37 brakuje danych), kiedy prof. J. Kostrzewski wymieniony jest jako kierownik, ale po tym okresie M.S. Ruxerówna widnieje w publikacjach dotyczących Uniwersytetu ponownie jako kierownik Seminarium w latach 1937/38 oraz $1938 / 39^{21}$. Warto odnotować również fakt pojawiania się w Seminarium Archeologii Klasycznej współpracowników, funkcjonujących $\operatorname{tam} \mathrm{z}$ powołaniem na okres danego roku akademickiego w charakterze albo młodszych asystentów, albo asystentów - jako zastępujących kierownika $^{22}$. I tak w ,Składzie" za lata 1925/26 i 1926/27 wymieniona jest Izabela Wojcińska, za lata 1927/28 i 1928/29 Stanisława Gorecka, za lata akademickie 1929/30, 1930/31 oraz 1931/32 Alina Boettnerówna, dalej za rok 1932/33 Wacław Kochański, za

rok 1933/34 brakuje danych, a następnie przez dwa lata (1934/35 i 1935/36) Tadeusz Wieczorowski - funkcjonujący oficjalnie jednak tylko jako współpracownik z zakresu prehistorii; natomiast w ostatnich dwóch latach przedwojennych, odpowiednio w roku 1937/38 ks. Franciszek Czyż, a w roku 1938/39 - Franciszka Labochówna ${ }^{23}$.

Ze względu na wspomniany poboczny charakter kursów z zakresu archeologii klasycznej, jej absolwentów nie było, gdyż seminarium kończyli studenci zgłębiający inne dyscypliny nauki jako kursy główne ${ }^{24}$. Jeśli chodzi o uczestników zajęć, to

\footnotetext{
${ }^{18}$ Zob. seria wydawnictw źródłowych Skład Uniwersytetu za rok akademicki... i stosownie: 1923/24, 33; 1924/25, 29; 1925/26, 32; 1926/27, 34; 1927/28, 34; 1928/29, 40; 1929/30, 39; 1930/31, 47; 1931/32, 30; 1932/33 (Spis Wyktadów i Sktad Uniwersytetu...), 120; 1933/34 - brak Sktadu.

${ }^{19}$ Sktad Uniwersytetu i Spis Wykładów za rok akad. 1934/35, 45.

${ }^{20}$ Kronika Uniwersytetu Poznańskiego za rok szkolny 1935/36, 136.

${ }^{21}$ Sktad Uniwersytetu w roku... i stosownie 1937/38, 58; 1938/39, 56.

${ }^{22}$ Kaczmarek 1996, 118.

${ }^{23}$ Por. przypisy nr 18-22.

${ }^{24}$ Kaczmarek 1996, 111.
} 
na podstawie „Kronik Uniwersytetu Poznańskiego” tylko w przybliżeniu oszacować można, iż w kursach archeologii klasycznej udział brało od kilku do kilkunastu osób, przy czym bywały także lata z wymienioną liczbą ponad 20, a nawet ponad 30 studentów $^{25}$. M.S. Ruxerówna, o której się wzmiankuje jako o osobie mającej się odznaczać charakterem skomplikowanym, ale i pięknym oraz ofiarnym, a przy tym niepospolitą inteligencją, przenikliwością, wielostronnością zainteresowań, a przede wszystkim dużą wiedzą ${ }^{26}$, miała, jak się wydaje, równie wielki zapał i chęć działania. Podjęła się z entuzjazmem przygotowania całego cyklu zajęć dydaktycznych o niezmiernie szerokiej problematyce, które były przez kolejne lata jej pracy systematycznie dopracowywane, a co więcej, przywoływane już wyżej archiwalne „Spisy Wykładów Uniwersytetu Poznańskiego" wskazują, iż nieliczne zajęcia były powtarzane. Wygląda na to, że powtarzano przeważnie zajęcia dla studentów początkujących, które dotyczyły ogólnej problematyki związanej z rzeźbą, ceramiką oraz architekturą starożytną ${ }^{27}$. Dla bardziej zaawansowanych słuchaczy co roku M.S. Ruxerówna ogłaszała nowe tematy, a były to między innymi takie zagadnienia, jak: historia rzeźby greckiej i rzymskiej, historia stroju w starożytności klasycznej, objaśnianie archeologiczne fragmentów Homera, wzajemne wpływy kulturalne Azji Przedniej i Grecji, wpływ kultury Azji Przedniej na kulturę kreteńsko-mykeńską, greckie kolonie na wybrzeżu Morza Czarnego, wpływy greckich kolonii czarnomorskich na sztukę scytyjską oraz na późniejszą sztukę tych obszarów, Rzym - topografia miasta, jego dzieje i zabytki, drogi handlowe świata grecko-rzymskiego, portret grecko-rzymski, świątynia grecka - jej geneza i rozwój, przemysł artystyczny w Grecji, Egipt hellenistyczny, jego sztuka i przemysł artystyczny, kultura egejska, kultura etruska, wpływy kultury Wschodu na powstanie sztuki greckiej, problemy artystyczne sztuki greckiej IV w. przed Chr., sztuka rzymska wieku II i III po Chr. i wiele innych ${ }^{28}$.

Dane archiwalne wskazują również, iż w latach 30. XX w. myślano nawet o przygotowaniu programu dla studiów archeologii klasycznej, jako przedmiotu głównego, zakończonego stopniem naukowym, a nie pobocznego jak dotąd, a w pracach takich brał udział sam J. Kostrzewski. Program został nawet wstępnie przyjęty przez władze Uniwersytetu, a po zatwierdzeniu habilitacji M.S. Ruxerówny, która odbyła się w 1937 r. w Uniwersytecie Jagiellońskim ${ }^{29}$ i wystąpieniu przez

\footnotetext{
${ }^{25}$ Por. przypis 17, w tym np. Kronikę Uniwersytetu Poznańskiego za lata szkolne 1929/30 i $1930 / 31,70$

${ }^{26}$ Gąsiorowski 1959, 500; Kubczak 1957, 177-179.

${ }^{27}$ Kaczmarek 1996, 117, 118.

${ }^{28}$ Zob. seria wydawnictw źródłowych Uniwersytet Poznański. Spis Wykładów..., a w nich opis: Archeologia klasyczna. Ruxerówna M., Dr. Zast. Prof. i jej zajęcia, które wymieniane są kolejno z podziałem na trzy trymestry, między innymi w latach akademickich 1930/31, 57; 1931/32, 59; 1932/33, 46; 1933/34, 47; 1934/35, 123; 1935/36, 127, 128; por. Kaczmarek 1996, 117, 118.

${ }^{29}$ Archiwum UAM, AMSR, sygn. 153-123.
} 
Uniwersytet Poznański w 1939 r. o tytuł profesora nadzwyczajnego dla niej, zaistniała nadzieja zmiany statusu Seminarium Archeologii Klasycznej z katedry pomocniczej na zwykłą - niestety planom tym przeszkodziła wojna ${ }^{30}$. Aby ukończyć ów niedoszły, samodzielny program studiów w zakresie archeologii klasycznej w Poznaniu, zgodnie z rozporządzeniem ministerstwa, opublikowanym w „Dzienniku Urzędowym MWRiOP” nr 12 poz. 237, należało zaliczyć obowiązkowo następujące przedmioty: archeologię przedhistoryczną z uwzględnieniem Basenu Morza Śódziemnego i Bliskiego Wschodu, historię starożytną z epigrafiką grecką i łacińską, archeologię klasyczną z metodologią i dziejami badań, historię sztuki oraz główne zasady nauki filozofii. Do wyboru ponadto były: historia i kultura Bizancjum, egiptologia, asyriologia, etnologia, socjologia lub antropologia. Przed egzaminem końcowym należało się również wykazać odbytą praktyką terenową co najmniej przez sezon, albo też trzymiesięczną praktyką muzealną ${ }^{31}$.

Jak powyżej wspomniano, tym ambitnym planom na drodze stanęła wojna. W Poznaniu po wybuchu II wojny światowej gestapo szybko zamknęło Uniwersytet, a władze okupacyjne już w październiku 1939 r. postanowiły utworzyć niemiecką uczelnię i zwróciły się z tym do Hitlera, uzyskując jego aprobatę. Jednak tzw. Uniwersytet Rzeszy w Poznaniu (niem. Reichsuniversität Posen) założony został dopiero w kwietniu 1941 r. i bazował na przybyciu do stolicy Wielkopolski przesiedlonych tutaj w 1940 r. z krajów nadbałtyckich niemieckich uczonych. Nie zajmowano się w nim kształceniem w zakresie archeologii klasycznej, wielki nacisk położony był natomiast na problematykę Wschodu wraz z elementami wczesnego zniemczenia tych obszarów, a zatem również na prehistorię i jej propagandowe wykorzystanie (utworzono Instytut Prehistorii) oraz badania archeologiczne w tzw. Kraju Warty ${ }^{32}$. W czasie II wojny wielu wykładowców Uniwersytetu Poznańskiego, ze względu na prześladowania, ukrywało się, część została zgładzona ${ }^{33}$, niektórzy natomiast konspiracyjnie nauczali w ramach tzw. Uniwersytetu Ziem Zachodnich ${ }^{34}$. Interesująca nas Mieczysława S. Ruxer spędza te lata w Krakowie, do którego przedostaje się z Kielecczyzny, gdzie była przesiedlona. W stolicy Małopolski udaje jej się z czasem otrzymać skromne płatne zajęcie w Muzeum XX. Czartoryskich, co umożliwia jej zarówno byt, jak i pracę naukową, jakiej się intensywnie podjęła, uczestnicząc ponadto również w tajnym nauczaniu Uniwersytetu Jagiellońskiego. Niemniej lata okupacji oraz pierwsze lata po wojnie należą do najcięższych w życiu Uczonej ${ }^{35}$.

Po II wojnie światowej, od samego początku, kiedy podjęto nauczanie w pierwszym, skróconym roku akademickim, trwającym na Uniwersytecie Poznańskim od

\footnotetext{
${ }^{30}$ Kaczmarek 1996, 118.

${ }^{31}$ Kaczmarek 1996, 118.

${ }^{32}$ Łuczak 1999, 175, 176; Kaczmarek 1996, 152.

${ }^{33}$ Euczak 1999, 179.

${ }^{34}$ Łuczak 1999,183-197.

${ }^{35}$ Gąsiorowski 1959, 499, 500; Liman 1992, 266, 267; Kubczak 1998, 49.
} 
kwietnia do września 1945 r., funkcjonowało Seminarium Archeologii Klasycznej, działające ponownie pod kierunkiem M.S. Ruxerówny, która powróciła do Poznania od razu na początku 1945 r. $^{36}$ Niestety Katedrę i Zakład trzeba było w trudnych warunkach powojennych z mozołem organizować na nowo, gdyż całe przedwojenne wyposażenie i zbiory zostały zniszczone lub wywiezione. Pomimo kłopotów ze zdrowiem M.S. Ruxerówna podejmowała wyprawy w celu pozyskiwania (ratowania) niezbędnych pomocy naukowych - między innymi na Pomorze, gdzie w zniszczonych muzeach, pałacach i dworach można było znaleźć stosowne zbiory, a głównie książki ${ }^{37}$. Po zorganizowaniu na nowo Katedra i Zakład Archeologii Klasycznej w 1945 r. mieściły się początkowo w Collegium Marianum przy ul. Różanej 17, a po paru miesiącach otrzymały lokal w remontowanym Collegium Maius (ówczesny jego adres: al. Stalingradzka 1). Zajęcia z kolei, podobnie jak te z zakresu prehistorii, odbywały się w Muzeum Wielkopolskim. W pierwszym okresie powojennego funkcjonowania, tj. w latach 1945-1952, przy Katedrze i Zakładzie Archeologii Klasycznej wymieniani są także pomocniczy pracownicy nauki, a Mieczysława S. Ruxer czyni starania o trwałe zatrudnienie asystenta lub asystentki. Wspomnianymi pomocnikami byli: Bogdan Hofman, mł. asystent 1945/46, Michalina Kwiczalanka, mł. asystent 1947/48, Bolesława Kühnówna, mł. asystent 1948/49, Henryk Kowalewicz, mł. asystent 1950/51, Edwin Dzięciołowski, zast. asystenta 1950/51, Jerzy Kubczak, zast. asystenta od 1951 do 1952 r., a po uzyskaniu stopnia magistra w zakresie archeologii klasycznej, asystent od roku $1953 / 54^{38}$.

Początek pierwszego, pełnego roku akademickiego (1945/46) na Uniwersytecie Poznańskim ustalono na 1 listopada 1945 r. Organizacja studiów początkowo była podobna jak przed wojną - na Wydziale Humanistycznym nie obowiązywał podział na poszczególne lata, określona była minimalna liczba trymestrów, to jest 12 , oraz liczba godzin zajęć do zaliczenia w trymestrze, która miała być nie mniejsza niż 10 . Nie wiadomo, ilu dokładnie studentów wybrało w pierwszych latach powojennych jeden z kierunków archeologicznych, a szczególnie trudne jest to w przypadku archeologii klasycznej, aczkolwiek po wojnie można ją już było studiować nie tylko jako kierunek poboczny, lecz także i główny ${ }^{39}$, a stan taki trwał do roku 1952.

Przy wyborze archeologii klasycznej, jako kierunku głównego, warunkiem przyjęcia na niego była znajomość łaciny i greki; dwa języki nowożytne można było zaliczyć w trakcie studiów. Jako przedmioty do wyboru wymieniano archeologię starożytnego Wschodu, historię i kulturę Bizancjum, egiptologię, asyriologię, etnologię, socjologię lub antropologię. Egzaminy na tym kierunku składano z następujących działów: 1) archeologii przedhistorycznej z podkreśleniem basenu Morza

\footnotetext{
${ }^{36}$ Zob. Kronika Uniwersytetu Poznańskiego za lata akademickie 1945-1954/55, 321.

${ }^{37}$ Archiwum UAM, AMSR, sygn. 191.

${ }^{38}$ Kronika Uniwersytetu Poznańskiego za lata akademickie 1945-1954/55, 371, 372.

${ }^{39}$ Kaczmarek 1996, 231, 247.
} 
Śródziemnego; 2) historii starożytnej z epigrafiką grecką i łacińską; 3) języka i literatury greckiej i łacińskiej; archeologii klasycznej z metodologią i historią badań; historii sztuki ${ }^{40}$.

Należy tutaj wspomnieć, że lata powojenne - niezmiernie trudne z wielu względów - to próba odbudowy życia naukowego w Polsce, co wiązało się z koniecznością ponownej organizacji instytucji naukowych, a w nowej sytuacji politycznoideologicznej wywoływało liczne spory, a nawet konflikty. Owa odbudowa życia naukowego, zarówno na gruncie badań i ochrony dóbr kultury, jak i szkolnictwa, postępowała najczęściej, pomimo niezmiernej ofiarności i zaangażowania wielu przedwojennych uczonych, według odgórnie narzucanych wzorów, niejednokrotnie podporządkowanych nauce sowieckiej. W dziedzinie organizacji instytucji naukowych postępował w całej Polsce proces ujednolicania i centralizacji - czego wyrazem była w pewnej mierze przymusowa integracja archeologii pradziejowej i klasycznej (zwanej z czasem śródziemnomorską) oraz etnografii w celu wspólnych badań nad kulturą materialną ${ }^{41}$. Był to skutek wprowadzenia na polu badań naukowych filozofii materialistycznej jako obowiązującego dogmatu, który szczególnie dotkliwie odczuwano na gruncie humanistyki. Według A. Abramowicza momentem kluczowym w procesie narzucania społeczności archeologicznej metodologii marksistowskiej była konferencja archeologów i etnografów zorganizowana w czerwcu 1951 r. w Nieborowie. Miała ona na celu przedyskutowanie węzłowych zagadnień archeologii (Polski i klasycznej) oraz etnografii i przyspieszenie przełomu metodologicznego według założeń marksizmu-leninizmu oraz stworzenie podstaw współpracy naukowej zainteresowanych dyscyplin $w$ ramach historii kultury materialnej ${ }^{42}$. Nauki historyczne, w tym archeologia, miały się zajmować poznaniem rozwoju sił wytwórczych, stosunków produkcji i nadbudowy ideologicznej, z uwzględnieniem specyfiki etnicznej. Miarą natomiast wartości badań miało być kryterium ich postępowości ${ }^{43}$. W związku z toczonymi dyskusjami następowały też zmiany terminologii. Zaprzestano używać pojęcia „prehistoria” na rzecz „,prahistoria”, ,archeologia” zaczęła oznaczać głównie wszystkie dyscypliny historyczne posługujące się metodą wykopaliskową, natomiast, jak już wspomniano uprzednio, archeologię klasyczną stopniowo przemianowano na śródziemnomorską ${ }^{44}$.

Wzmiankowany powyżej przewrót metodologiczny rozgrywał się także w sferze organizacyjnej i zaznaczył między innymi reformę studiów uniwersyteckich w zakresie archeologii, która miała miejsce w 1950 r. Utworzono wówczas w głównych ośrodkach uniwersyteckich - w Krakowie, Warszawie, Wrocławiu oraz Poznaniu -

\footnotetext{
${ }^{40}$ Kaczmarek 1996, 247, 248.

${ }^{41}$ Kaczmarek 1996, 166.

${ }^{42}$ Abramowicz 1991, 150.

${ }^{43}$ Por. stosowne cytaty z lat 50. XX w. z powyższymi postulatami w: Kaczmarek 1996, 166.

${ }^{44}$ Abramowicz 1991, 152; Kaczmarek 1996, 166.
} 
Studium Historii Kultury Materialnej, ze wspólnymi zajęciami dla studentów archeologii pradziejowej, śródziemnomorskiej oraz etnografii na pierwszych trzech latach studiów. Dopiero następne dwa lata miały być przeznaczone na specjalizację w jednej z tych dyscyplin ${ }^{45}$. Takie zmiany przeszedł także Wydział Humanistyczny Uniwersytetu Poznańskiego. Od 1950 r. powołano na nim ów nowy kierunek historię kultury materialnej, będący połączeniem dawnej prehistorii, archeologii klasycznej i etnografii. Zmieniono zasady studiowania - wprowadzono sztywne programy nauczania oraz większą dyscyplinę pracy wykładowców i słuchaczy; wprowadzono również ścisłe podziały na lata, zniesiono możliwość względnie swobodnego wyboru przez studentów przedmiotów oraz swobodę ustalania kolejności zdawania egzaminów. Obok dotychczasowych studiów jednolitych, trwających 8-11 semestrów, zaczęto wprowadzać także studia dwustopniowe - pierwsze, zawodowe, trwające 6-8 semestrów - kończące się stopniem licencjata; drugie - magisterskie, mające przygotować ewentualnie do dalszej pracy naukowej ${ }^{46}$. Wspomnieć warto, że kroki powyższe, najczęściej dyktowane przesłankami ideologicznymi, które wypada ocenić negatywnie, do pewnego stopnia powodowane były także przesłankami praktycznymi oraz ekonomicznymi, tzn. chciano szybciej pozyskać stosownie wykwalifikowane kadry do pracy zawodowej, a ponadto studia przestały być odpłatne, państwo podejmowało rozmaite kroki, aby móc sprostać wydatkom na tym polu.

Na marginesie przybliżania owych powojennych dziejów archeologii trzeba zaznaczyć, iż jeśli chodzi o archeologię klasyczną, oceniając jednoznacznie negatywnie narzucanie jej zasad marksizmu jako podłoża, na którym miała oprzeć swe badania oraz tendencje całkowitego upolitycznienia, to - paradoksalnie - wskazywane jej pójście w kierunku badań całej kultury materialnej antyku, a nie tylko dzieł sztuki, spowodowało niewątpliwie znaczące poszerzenie tematyki jej studiów, jak również zbliżenie z zakresami poznawczymi prehistoryków, z wykorzystaniem ogromnego dorobku etnografii $w$ badaniach nad kulturą ludową jako istotnego tła porównawczego. Studia takie miały być przy tym przede wszystkim elementem badań historycznych, postulowano zatem także o wiele większe ich scalenie w ramach perspektywy historycznej, jako stosownej dla postępowania badawczego na ich gruncie. Wyjątkowo aktywnie na polu takiej integracji zaczął działać archeolog klasyczny Kazimierz Majewski, którego udział we wspomnianej konferencji w Nieborowie związany był z przedstawieniem ówczesnego (czyli w zasadzie przedwojennego) dorobku całej polskiej archeologii klasycznej oraz planu jej rozwoju na przyszłość, co zresztą ogłosił drukiem w roku $1952^{47}$. Pomimo noszącego znamiona retoryki czasów stalinizmu wstępu owego tekstu i powtórzonego w nim za postulatami Ko-

\footnotetext{
${ }^{45}$ Abramowicz 1991, 151.

${ }^{46}$ Zob. Kronika Uniwersytetu Poznańskiego za lata akademickie 1945-1954/55, 323; Kaczmarek

${ }^{47}$ Majewski 1952, 233-265.
} 1996, 178. 
mitetu Organizacyjnego I Kongresu Nauki Polskiej (1951 r.) nawoływania do: „,zastanowienia się nad sposobami powiązania nauki z życiem i przyszłością idącej do socjalizmu Polski Ludowej i wytypowania zagadnień naukowych, które mają cha-

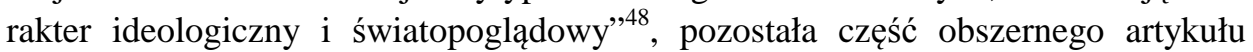
omawia dosyć rzetelnie wkład polskiej archeologii klasycznej do nauki światowej, wskazując wyraźnie jej kierunek rozwoju w ramach wspomnianych studiów nad kulturą materialną. Zostanie to chyba najlepiej zrealizowane w powołanym do życia 19 listopada 1953 r. Instytucie Historii Kultury Materialnej Polskiej Akademii Nauk (obecnie Instytut Archeologii i Etnologii PAN) ${ }^{49}$, w którym prof. K. Majewski na rok obejmuje stanowisko dyrektora (1953/54), aby następnie kierować (do swej emerytury) pracami i wydawnictwami Zakładu Archeologii Antycznej IHKM PAN. Do promowanej przez siebie wizji uprawiania archeologii klasycznej, a więc jak sam napisał w kolejnym podsumowaniu badań prowadzonych w Polsce na tym gruncie - historii sztuki i kultury materialnej grecko-rzymskiej ${ }^{50}$, powraca w połowie lat 60. XX w., naświetlając wiele pozytywów dotychczasowego jej rozwoju, ale zauważając również niepokojący proces dehumanizacji nauk historycznych, szczególnie tych uprawianych i wykładanych na kanwie uniwersyteckiej, który należałoby powstrzymać ${ }^{51}$.

Po powyższych konstatacjach ogólniejszej natury, wracając jednak do Poznania, zauważyć trzeba, iż owa powojenna, z reguły bardzo brzemienna niestety w skutkach i dogłębna przebudowa nauki w Polsce nie ominęła także Zakładu Archeologii Klasycznej na Uniwersytecie Poznańskim. Po pierwsze jej dalsze losy po udanej reaktywacji w 1945 r., o której wspomniano, nie były wcale pewne, gdyż M.S. Ruxerówna nie przejawiała zupełnie zrozumienia dla korzyści ze stosowania marksi$\mathrm{zmu}^{52}$. W archiwum Uniwersytetu można znaleźć na przykład informację, iż Uczona, nieakceptująca nowych porządków, protestowała w rozmaity sposób, między innymi zmuszana do obecności $\mathrm{w}$ pochodzie pierwszomajowym, przedstawiła w 1948 r. zaświadczenie lekarskie o cierpieniu od wielu lat na poważne powikłania chorobowe, z powodu których jej udział w wielogodzinnych uroczystościach jest niewskazany. W tym samym czasie jednak, pomimo rzeczywistego podupadania na zdrowiu, znajdowała zawsze dosyć sił, aby objeżdżać Ziemie Zachodnie w poszukiwaniu książek do biblioteki ${ }^{53}$. Ponieważ jednak w swej dziedzinie na Uniwersyte-

${ }^{48}$ Majewski 1952, 233.

${ }^{49}$ Zob. strona domowa Instytutu - www.iaepan.edu.pl [dostęp: lipiec 2013].

${ }^{50}$ Majewski 1965, 310.

${ }^{51}$ Majewski 1965, 312.

${ }^{52} \mathrm{Na}$ marginesie warto dodać, iż takiego zrozumienia absolutnie nie przejawiał także ówcześnie już nestor archeologii poznańskiej oraz polskiej - prof. Józef Kostrzewski, którego jesienią 1950 r. wysłano z Uniwersytu na przymusową emeryturę; na katedrę powołano go ponownie po tzw. odwilży w 1956 r. zob. Abramowicz 1991, 151; Kaczmarek 1996, 170, 171.

${ }^{53}$ Kaczmarek 1996, 210. 
cie nie miała konkurenta, zatem do początków 1952 r. zachowała stanowisko kierownika Katedry i Zakładu Archeologii Klasycznej, które w 1949 r. otrzymała. Sprawa była ponadto delikatna, gdyż również w tymże 1949 r. była mianowana na stanowisko profesora nadzwyczajnego (przez Bolesława Bieruta), na co czekała zresztą 10 lat, od czasu jak Senat Uniwersytetu wystąpił o to już przed wojną, w roku 1939. W 1951 r. pojawił się ponadto w Katedrze etat zastępcy asystenta został nim Jerzy Kubczak ${ }^{54}$. W roku akademickim 1951/52 Katedra weszła w skład Zespołu Katedr Historii Kultury Materialnej, natomiast w 1952 r. nazwa jej została zmieniona na Katedrę Archeologii Śródziemnomorskiej ${ }^{55}$. Na tym niestety zmiany się nie zakończyły i reorganizacja postępowała. Mianowicie decyzją Ministerstwa z dniem 1 maja 1952 r. M.S. Ruxerównę przeniesiono do Katedry Historii Sztuki ${ }^{56}$, pozbawiając tym samym kierownictwa jednostki, podobnie zresztą Katedra i Zakład Archeologii Śródziemnomorskiej weszły w skład Katedry Zespołowej Historii Sztuki. Przez jakiś czas stanowisko kierownika Katedry Archeologii Śródziemnomorskiej nie było obsadzone, a funkcję kuratora pełnił prof. Witold Hensel ${ }^{57}$, który, po odsunięciu w 1950 r. prof. Józefa Kostrzewskiego od pracy w Uniwersytecie, stał się postacią pierwszoplanową poznańskiej archeologii, organizując między innymi Zespół Katedr Historii Kultury Materialnej UP oraz nowy wydział, jak również obejmując ich kierownictwo ${ }^{58}$. Warto bowiem także wspomnieć, iż Wydział Humanistyczny przemianowano w 1952 r. na Historyczno-Filozoficzny, wydzielając z niego jako odrębną jednostkę nauki filologiczne.

Profesor M.S. Ruxer prowadziła w owych trudnych powojennych latach transformacji liczne wykłady na temat sztuki starożytnej - greckiej, etruskiej i rzymskiej, zarówno dla historyków sztuki, prehistoryków, filologów, jak i słuchaczy Wyższej Szkoły Sztuk Plastycznych, a ponadto ćwiczenia seminaryjne dotyczące stroju i ceramiki. Magister J. Kubczak prowadził w Studium Kultury Materialnej ćwiczenia z rozmaitych aspektów kultury materialnej społeczeństw antycznych, tj. niewolniczych, jak wówczas wyłącznie je nazywano, uwypuklając szczególnie ten ich aspekt $^{59}$. W kronice uniwersyteckiej brakuje jednak dalszych danych na temat działalności Zakładu Archeologii Śródziemnomorskiej po roku 1952, aczkolwiek z innych przesłanek wiadomo, że dydaktyka była kontynuowana.

\footnotetext{
${ }^{54}$ Kaczmarek 1996, 248, 249 oraz Archiwum UAM, AMSR, sygn. 82-385.

${ }^{55}$ Zob. Kronika Uniwersytetu Poznańskiego za lata akademickie 1945-1954/55, 371; Kaczmarek 1996, 178.

${ }^{56}$ Archiwum UAM, AMSR, sygn. 82-385.

${ }^{57}$ Kronika... za lata akademickie 1945-1954/55, 372.

${ }^{58}$ Kronika... za lata akademickie 1945-1954/55, 370, 371; można wspomnieć, iż prof. W. Hensel z czasem przenosi się do Warszawy, gdzie zostaje w 1955 r. dyrektorem IHKM PAN i stanowisko to piastuje aż do $1989 \mathrm{r}$.

${ }^{59}$ Kronika... za lata akademickie 1945-1954/55, 372.
} 
Ostatecznie w roku akademickim 1955/56 zawieszono działalność Zakładu Archeologii Śródziemnomorskiej, a mgr J. Kubczak został zwolniony ${ }^{60}$. Wówczas opuścił na trzy lata Uniwersytet, podejmując obowiązki asystenta w poznańskim Muzeum Narodowym. Co więcej, w 1957 r. śmierć wyrwała z Wydziału Filozoficzno-Historycznego prof. dr Mieczysławę Sabinę Ruxer, pracującą od lat pięciu przy Katedrze Historii Sztuki, a jej zgon oznaczał ciężką i niepowetowaną stratę dla Uniwersytetu, co dobitnie podkreślał w sprawozdaniu ówczesny dziekan, prof. Janusz Pajewski ${ }^{61}$. W tym czasie, co wydaje się warte podkreślenia w kontekście trudnych losów poznańskiej archeologii klasycznej, w 1956 r. Zespół Katedr Historycznych przekształcony został w Instytut Historyczny, a w Katedrze Historii Powszechnej funkcjonował między innymi Zakład Historii Starożytnej, którego docent, Tadeusz Zawadzki, będący także członkiem Zakładu Archeologii Antycznej IHKM PAN, brał udział w ekspedycji Archeologicznej do Olbii nad Bohem ${ }^{62}$. Wiadomo ponadto, iż w tym samym roku (1956) pracę w Katedrze i Zakładzie Historii Sztuki chwilowo podjął specjalista w zakresie archeologii śródziemnomorskiej, wspominany już prof. Kazimierz Majewski, prowadząc wykłady o charakterze monograficznym na temat wybranych zagadnień sztuki starożytnej. Wykłady te jednak w roku następnym zawiesza ${ }^{63}$.

Należy odnotować także fakt zmiany w 1955 r. nazwy Uniwersytetu - z Poznańskiego na Uniwersytet im. Adama Mickiewicza. Na gruncie archeologii istotną zmianą było natomiast wycofanie się ostatecznie $\mathrm{z}$ pomysłu nauczania jedynie w ramach tzw. historii kultury materialnej, co następowało powoli po roku 1956. Przestał również wówczas istnieć na UAM Zespół Katedr Historii Kultury Materialnej, a katedry Wydziału odzyskały samodzielnośćc ${ }^{64}$. Studenci mogli jednak ukończyć studia według dotychczasowego programu.

W miejscu tym chcę dodać jeszcze kilka słów na temat dorobku naukowego prof. M.S. Ruxer, która według znających ją badaczy oraz uczniów wyróżniała się ogromną wiedzą ${ }^{65}$, ukierunkowaną szczególnie na sztukę antyczną, ale również na jej europejską spuściznę, jak i odnośną sztukę orientalną. Uczona nie pozostawiła wielkiej liczby publikacji ogłoszonych drukiem ${ }^{66}$, jednakże wyjątkowe zainteresowania dotyczące rzemiosła artystycznego, w tym szczególnie związane z biżuterią i złotnictwem, spowodowały, iż może poszczycić się oryginalnym i unikatowym na tle literatury światowej dorobkiem na temat naszyjnika antycznego, rozpatrywanego w bardzo szerokim kontekście. Jest nią monografia autorska: Historia naszyjnika

\footnotetext{
${ }^{60}$ Kronika... za rok szkolny 1955/56, 75.

${ }^{61}$ Kronika... za rok szkolny 1956/57, 107.

${ }^{62}$ Kronika... za rok szkolny 1956/57, 121-125.

${ }^{63}$ Kronika... za rok szkolny 1956/57, 130, 131.

${ }^{64}$ Kaczmarek 1996, 233.

${ }^{65}$ Gąsiorowski 1959, 500; Kubczak 1998, 50.

${ }^{66}$ Gąsiorowski 1959, 500.
} 
greckiego (1938), oraz współautorska, będąca kontynuacją merytoryczną poprzedniej, ukończona i opublikowana na podstawie manuskryptu przez ucznia i współpracownika, Jerzego Kubczaka - Naszyjnik grecki w okresach hellenistycznym i rzymskim (1972). Badaczka ogłosiła ponadto kilka znaczących artykułów dotyczących złotnictwa, omówiła całościowo biżuterię antyczną ze zbiorów XX. Czartoryskich w Krakowie, a ponadto szczególną uwagę poświęciła katalogowi gliptyki. Interesowała ją także ceramika, głównie grecka i etruska. Wszystkie jej prace cechuje wyjątkowa rzetelność analizy materiału zabytkowego. Wykorzystywała takie metody badawcze, jak atrybucjonizm oraz studia styloznawcze, a prace przeprowadzane były ze znawstwem i poparte świetną znajomością historii, a przy tym wzbogacane oryginalnymi przemyśleniami na temat kulturotwórczej roli omawianych źródef ${ }^{67}$.

Powracając do poznańskiej archeologii klasycznej, wypada zauważyć, iż po „odwilży”, pod koniec 1957 r. udało się ściągnąć z Wrocławia do Poznania archeologa klasycznego, dr. Stefana Parnickiego-Pudełko, pracującego początkowo w Katedrze Archeologii Klasycznej Uniwersytetu Wrocławskiego, a od 1953 r. w Zakładzie Archeologii Antycznej IHKM PAN w Warszawie. Po uzyskaniu mianowania na docenta dr Stefan Parnicki-Pudełko z dniem 1 października 1958 r. obejmuje kierownictwo reaktywowanej przy Wydziale Filozoficzno-Historycznym Katedry Archeologii Śródziemnomorskiej (mającej siedzibę w Collegium Maius ale zwany tak był wówczas już gmach przy ul. Fredry 10), a w 1959 r. powraca do niej także Jerzy Kubczak. Prace naukowe w Katedrze, którą uznać wypada za prawdziwą kontynuację dzieła prof. M.S. Ruxerówny, dotyczą przede wszystkim studiów nad architekturą starożytną oraz ceramiką antyczną, jak również nad kulturą kolonii antycznych na północnych wybrzeżach Morza Czarnego. Ponieważ Katedra pełniła funkcję usługową, zajęcia ze sztuki starożytnej i archeologii śródziemnomorskiej prowadzone były dla studentów historii sztuki, archeologii oraz filologii klasycznej $^{68}$.

Warto wspomnieć, że prof. S. Parnicki-Pudełko od 1960 r., regularnie bierze udział w badaniach ekspedycji wykopaliskowej IHKM PAN w starożytnym Novae, leżącym na terenie dzisiejszej Bułgarii (Swisztow nad Dunajem), którą zorganizował prof. K. Majewski, wielce zainteresowany rozwojem kultury rzymskiej oraz problematyką importów i kontaktów imperium rzymskiego ze społecznościami żyjącymi w starożytności na północ od limesu ${ }^{69}$. W takiej formie organizacyjnej Katedra Archeologii Śródziemnomorskiej w UAM funkcjonowała przez dziesięć lat - do

\footnotetext{
${ }^{67}$ Kubczak 1998, 50-53.

${ }^{68}$ Zob. seria Kronika Uniwersytetu im. Adama Mickiewicza w Poznaniu..., a tam opis: Katedra Archeologii Śródziemnomorskiej, stosownie: za rok akademicki 1958/59, 130, 131; za lata akademickie 1959/1962, 207, 208; za lata akademickie 1962/63-1964/65, 239-241; za lata akademickie 1965/661967/68, 224-228; za rok akademicki 1968/69, 183-185.

${ }^{69}$ Parnicki-Pudełko 1984, 13.
} 


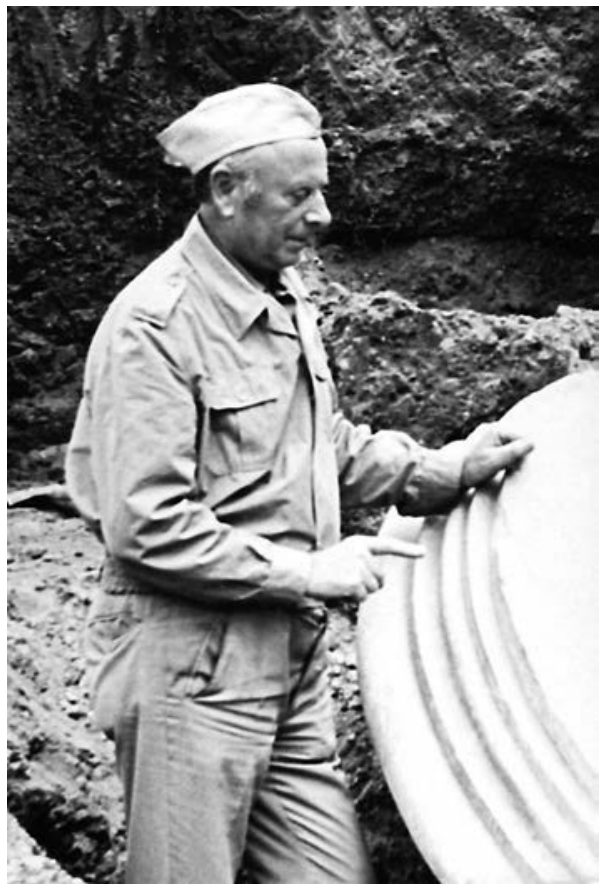

Ryc. 3. Stefan Parnicki-Pudełko w trakcie badań archeologicznych w Novae. Zdjęcie z archiwum Ekspedycji Novae w Instytucie Historii UAM

Fig. 3. Stefan Parnicki-Pudełko during an archaeological excavation of Novae. The photo from the archive of the Novae Expedition, Institute of History AMU do 1969 r., kiedy to została zlikwidowana 30 sierpnia $^{70}$. Prof. S. Parnicki-Pudełko i dr J. Kubczak przechodzą początkowo do Katedry Historii Sztuki (prof. Parnicki zostaje nawet jej kierownikiem), lecz po kilku miesiącach $\mathrm{z}$ powodów pozamerytorycznych ją opuszczają, ponieważ los jej w tym czasie wydaje się również niepewny. Ostatecznie prof. S. Parnicki-Pudełko obejmuje w 1970 r. kierownictwo powołanego wówczas Zakładu Historii Starożytnej w miejsce Katedry Historii Powszechnej Starożytnej, która w latach 1967-1969 nie miała kierownika, po tym jak wspomniany wcześniej prof. Tadeusz Zawadzki nie powrócił do Polski z zagranicy. W Zakładzie znalazł się także dr J. Kubczak ${ }^{71}$. Można zatem powiedzieć, iż Zakład Historii Starożytnej IH UAM powołany w 1970 r. powstał z połączenia obydwu Katedr - Historii Powszechnej Starożytnej i Archeologii Śródziemnomorskiej, przejmując zarówno ich obowiązki dydaktyczne, jak i plany naukowo-badawcze. Co więcej, wówczas dopiero następuje prawdziwe włączenie

ośrodka poznańskiego w badania wykopaliskowe na obszarach kultur śródziemnomorskich. Nastąpiło to w roku 1970, wtedy bowiem prace wykopaliskowe na terenie rzymskiego obozu legionowego w Novae (obszar starożytnej Moesia Inferior) rozpoczęła samodzielna Ekspedycja Archeologiczna Uniwersytetu im. Adama Mickiewicza w Poznaniu, utworzona i kierowana od 1970 do 1988 r. właśnie przez prof. S. Parnickiego-Pudełko ${ }^{72}$. Działa ona do dziś, obecnie jako Międzynarodowa Interdyscyplinarna Ekspedycja Archeologiczna Uniwersytetu im. Adama Mickiewicza w Poznaniu, funkcjonująca przy Instytucie Historii UAM, pod kierownictwem, od 1990 r. dr. Andrzeja B. Biernackiego. Jej prace od wielu lat obejmują także obszar

\footnotetext{
${ }^{70}$ Kronika... za lata akademickie 1969/70-1971/72, 212

${ }^{71}$ Kronika... za lata akademickie 1969/70-1971/72, 212.

${ }^{72}$ Kronika... za lata akademickie 1969/70-1971/72, 213.
} 
Chersonezu Taurydzkiego i prowadzone są we współpracy z badaczami ukraińskimi $^{73}$.

Doktor Jerzy Kubczak w 1974 r. opuszcza jednak historyków starożytności i podejmuje pracę w Instytucie Historii Sztuki, który zresztą wówczas przekształcony został z uprzedniej Katedry w Instytut; pracuje najpierw w ramach Zakładu Historii Rzemiosła Artystycznego, a następnie po otrzymaniu profesury nadzwyczajnej UAM w powołanym w 1986 r. Zakładzie Historii Sztuki Starożytnej, jedynej tego rodzaju jednostce naukowej w Polsce, którym aż do swej śmierci w 1999 r. kierowal ${ }^{74}$. Zakład ten niestety w 2007 r. uległ ograniczeniu i funkcjonował w strukturach IHS UAM jako Pracownia Sztuki Starożytnej, kierowana przez prof. Tomasza Wujewskiego, a ostatnio (rok akademicki 2012/13) specjaliści w zakresie sztuki starożytnej wchodzą w skład Zakładu Historii Sztuki Średniowiecznej ${ }^{75}$.

Wypada jeszcze odnieść się bardzo

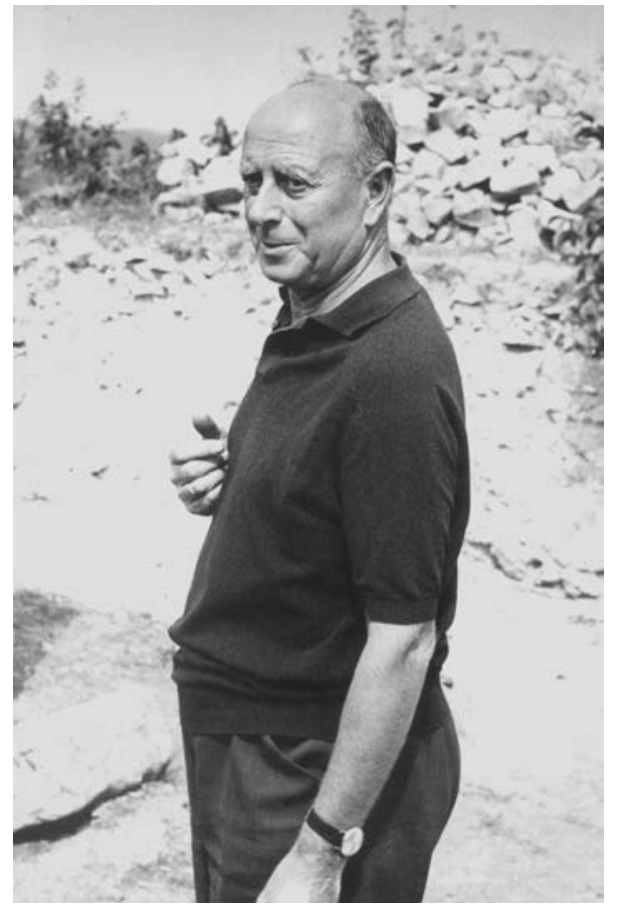

Ryc. 4. Stefan Parnicki-Pudełko (1914-1994). Zdjęcie z archiwum Ekspedycji Novae w Instytucie Historii UAM

Fig. 4. Stefan Parnicki-Pudełko (1914-1994). The photo from the archive of the Novae Expedition, Institute of History AMU zwięźle do dorobku naukowego profesorów - Stefana Parnickiego-Pudełko i Jerzego Kubczaka, których prace badawcze wiążą się głównie z poznańską, uniwersytecką archeologią klasyczną.

Profesor S. Parnicki-Pudełko był przede wszystkim wybitnym znawcą starożytnej sztuki budowlanej, pozostawiając nam w spuściźnie, wśród licznych innych prac, monografię na ten temat (Architektura starożytnej Grecji, 1975). Zajmowały go wcześniej także kwestie dotyczące starożytnej urbanistyki, której poświęcił cykl artykułów, a ich zwieńczeniem była monografia: Agora. Geneza i rozwój rynku greckiego (1957). Opublikował ponadto książeczkę nakreślającą zabudowę Olimpii (Olimpia i olimpiady, 1964), a wcześniej topografię i zabudowę Olbii (1957). Z kolei

\footnotetext{
${ }^{73}$ Biernacki, Szymkiewicz 2003, 10, 38-42.

${ }^{74}$ Wujewski 2000, 110.

${ }^{75}$ Zob. strona domowa Instytutu Historii Sztuki UAM - www.arthist.amu.edu.pl [dostęp: lipiec
} 2013]. 


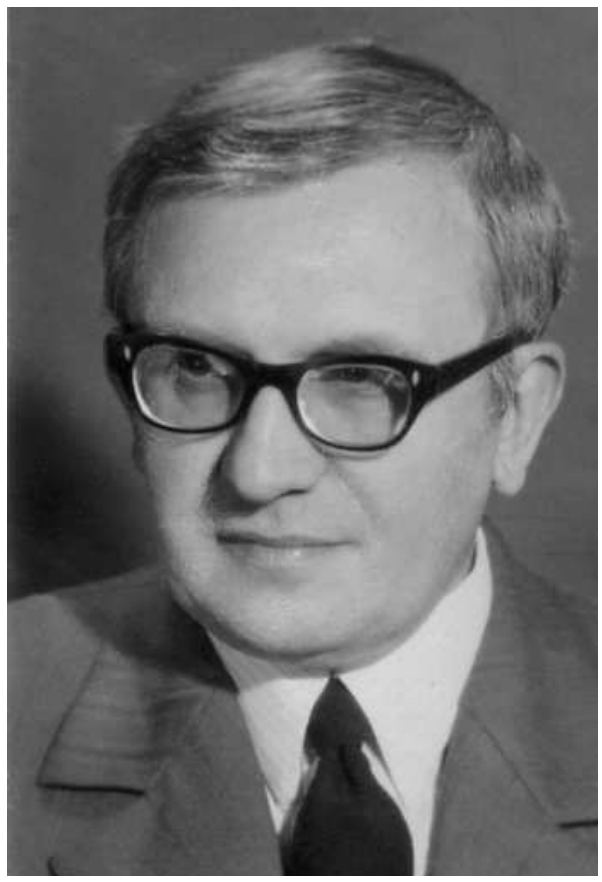

Ryc. 5. Jerzy Kubczak, lata 70. XX w. Zdjęcie z Archiwum UAM, Akta J. Kubczak, sygn. 467

Fig. 5. Jerzy Kubczak, 1970s. The photo from the AMU Archive, Personal dossier of J. Kubczak, reference No. 467 ważnym jego przedsięwzięciem było również całościowe opracowanie budownictwa greckiego w aspekcie kultury materialnej, wydane najpierw w książce z 1962 r., a następnie w stosownie opracowanym rozdziale źródłowej publikacji z serii „Kultura materialna starożytnej Grecji” (1977). Znajdziemy w nich omówioną bazę źródłową, technikę wraz z elementami budowlanymi, organizację pracy i same obiekty architektoniczne z podziałem na kategorie. Oprócz kładzenia akcentu na aspekt techniczny budowli oraz omówienie ich elementów strukturalnych, szczególną uwagę badacz poświęcał funkcjom omawianych obiektów, wskazując, iż są one wyrazem potrzeb wynikających $\mathrm{z}$ rozwoju życia społecznego. Istotne we wspomnianych i innych, licznych pracach było także mocne osadzenie omawianych źródeł w historii oraz uwypuklanie związków kulturowych i genetycznych. Wreszcie włączenie się w prace terenowe, które stanowiły jedną z pasji Uczonego, w tym szczególnie w te na obszarze starożytnej Mezji, w Novae, uwieńczone licznymi sukcesami kolejnych kampanii, m.in. takimi jak: odkrycie pozostałości bram miejskich i części murów, zlokalizowanie forum z ołtarzem i przylegającymi budowlami, odsłonięcie dużej bazyliki biskupiej, a ponadto wielu inskrypcji, rzeźb, naczyń i innych zabytków ruchomych ${ }^{76}$, umożliwiło prof. S. Parnickiemu-Pudełko opublikowanie licznych sprawozdań i opracowań szczegółowych oraz zainicjowanie periodycznej serii zeszytów naukowych UAM: „Novae - Sektor Zachodni” (1970 i nast.). Profesor S. Parnicki-Pudełko oceniany był jako uczony o wielkim autorytecie, jako dociekliwy i pracowity badacz oraz erudyta, co do dzisiaj poświadcza jego znaczący, sięgający ponad dwustu publikacji, dorobek naukowy ${ }^{77}$, tutaj zaledwie naszkicowany.

Profesor Jerzy Kubczak skupił swą uwagę badawczą, podobnie jak jego mistrzyni (tak nazywał zawsze prof. M.S. Ruxerównę, co wielokrotnie miałam okazję sły-

\footnotetext{
${ }^{76}$ Szerzej: Biernacki, Szymkiewicz 2003.

${ }^{77}$ Kubczak 1995, 289-294; Press 1995, 121-125.
} 
szeć $\mathrm{w}$ trakcie interesujących i ze swadą prowadzonych wykładów oraz jako uczestnik seminariów Profesora), na biżuterii starożytnej, a zwłaszcza na złotnictwie scytyjskim. Będąc kontynuatorem kierunku badań zapoczątkowanych przez Panią Profesor, mógł podjąć trud opracowania i wydatnego poszerzenia materiałów przez nią pozostawionych, o czym już wspominałam. Dzięki temu powstała książka współautorska: Naszyjnik grecki w okresach hellenistycznym i rzymskim (1972), a ponadto seria artykułów oraz pomniejszych opracowań, dotycząca zasobów zabytków starożytnej biżuterii w kolekcji Muzeum Czartoryskich w Krakowie ${ }^{78}$. Jak zaświadcza prof. Tomasz Wujewski, znający pozostawiony w rękopisach przez prof. M.S. Ruxerównę dorobek, praca ta wymagała

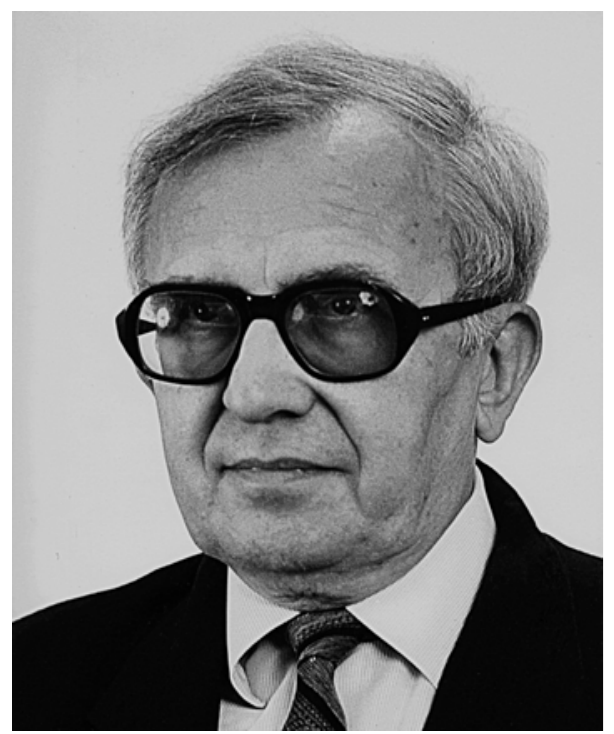

Ryc. 6. Jerzy Kubczak (1928-1999). Zdjęcie $\mathrm{z}$ archiwum Instytutu Historii Sztuki UAM

Fig. 6. Jerzy Kubczak (1928-1999). The photo from the archive of the Institute of History of Art AMU poświęcenia i benedyktyńskiej cierpliwości $^{79}$. Poza studiami nad złotnictwem starożytnym w kręgu zainteresowań badawczych prof. J. Kubczaka znalazło się również północne Nadczarnomorze oraz kultura scytyjska, przy czym złotnictwo owych obszarów pozostało istotnym elementem rozważań. Pokłosiem owego południowo-wschodniego, ważnego nurtu zainteresowań naukowych Profesora była jego habilitacja oraz książka Kurhany arystokracji scytyjskiej (1978). Podjął się w niej trudnego zadania ideowej interpretacji owych pomników grobowych i ich wyposażenia, gdyż rozpoznawanie znaczeń, odkrywanie symbolicznego wymiaru różnego rodzaju manifestacji kulturowych uważał za nieodzowny i zasadniczy element postępowania badawczego na gruncie archeologii i historii sztuki, a dotyczyło to niemal wszystkich jego studiów. Taka postawa sprawia, iż opracowania syntetyczne prof. J. Kubczaka wykraczają daleko poza ujęcia źródłoznawczo-historyczne; można znaleźć w nich wiele elementów metody ikonologicznej, niekiedy ślady inspiracji strukturalizmem - a zawsze uwrażliwienie na przekaz analizowanych dzieł. Niemniej problemy konwencji i przemian stylistycznych w sztuce, którą zajmował się najczęściej, nigdy mu nie umykały. Prace J. Kubczaka charakteryzują się także ujmowaniem rozpatrywanego zagadnienia czy źródeł i ich specyfiki na szerokim tle

\footnotetext{
${ }^{78}$ Śliwa 2007, 18, 19.

${ }^{79}$ Wujewski 2000, 110.
} 
porównawczym, a ujęciu takiemu sprzyjała zapewne niezwykła i stale pogłębiana erudycja, jaką się charakteryzował. Uczony podjął się również opracowania zabytków starożytnych, znajdujących się w poznańskim Muzeum Narodowym, które w znakomitej większości nie miały żadnej literatury, a najczęściej także znanej proweniencji ${ }^{80}$. Powstał na tej podstawie katalog rozumowany pt. Zbiory starożytności Muzeum Narodowego w Poznaniu (1983), do dnia dzisiejszego pozostający zasadniczym opracowaniem poznańskiej kolekcji. Profesor J. Kubczak jest ponadto autorem dwóch skryptów akademickich poświęconych architekturze greckiej i rzymskiej, bardzo pożytecznych w swoim czasie, jak również wielu studiów odnoszących się do rozmaitych aspektów historii i kultury północnopontyjskiej. Uzupełniając jego sylwetkę, warto wspomnieć o talentach popularyzatorskich, a nade wszystko dydaktycznych, jakimi się znacząco wyróżniał ${ }^{81}$. Wykłady jego były zawsze precyzyjnie przygotowane, klarownie zbudowane i starannie prezentowane; zresztą akrybia cechowała całą jego pracę i oczekiwał jej od seminarzystów. Z całą pewnością prof. Jerzego Kubczaka uznać wypada za wielką indywidualność, którą poszczycić się może poznańska archeologia klasyczna.

Powracając zatem do dalszych jej dziejów, można spostrzec, iż po roku 1968 i zamknięciu Katedry Archeologii Śródziemnomorskiej, tj. od początku lat 70. XX w., zainteresowania badaniami archeologicznymi w basenie Morza Śródziemnego w środowisku poznańskich uczonych, i tych związanych z Uniwersytetem, i tych spoza niego, nie tylko nie zmalały, ale niezmiernie wzrosły. Znalazło to wyraz w UAM przede wszystkim we wspomnianych już badaniach archeologicznych w Novae oraz w studiach nad społecznościami starożytnymi, prowadzonych w ramach historii starożytnej i historii sztuki, o czym wzmiankowałam. Natomiast poza Uniwersytetem zainteresowania kulturami basenu Morza Śródziemnego, przede wszystkim pradziejowymi, ujawniły się dobitnie w projektach naukowych realizowanych wspólnie z placówkami zagranicznymi na obszarach śródziemnomorskich, a głównie w północno-wschodniej Afryce, przez badaczy z Instytutu Archeologii i Etnologii PAN, Oddział w Poznaniu (prof. Michał Kobusiewicz), oraz z Muzeum Archeologicznego w Poznaniu (prof. Lech Krzyżaniak). Wypada także zwrócić uwagę, że w Polsce po historycznym przełomie roku 1989 i odzyskaniu suwerenności zaistniał klimat do odtwarzania wszystkich kulturowych więzi, jakie zawsze łączyły nasz kraj z Europą, a w przypadku wiodących ośrodków uniwersyteckich zaczęło przejawiać się to m.in. chęcią wskrzeszania funkcjonujących w przeszłości katedr i wykładanych dyscyplin, jak i generalną tendencją do znacznego poszerzania dotychczasowej oferty dydaktycznej oraz pola badań naukowych. W takiej atmosferze wysiłki i starania idące w kierunku powołania (reaktywowania) archeologii śródziemnomorskiej (lub klasycznej) rozwinęły się również w Uniwersytecie im. Adama

\footnotetext{
${ }^{80}$ Wujewski 2000, 110.

${ }^{81}$ Żuchowski 2007, 23-27.
} 
Mickiewicza. Bezpośrednimi jednak ich inicjatorami ze strony archeologicznej byli wspomniani powyżej profesorowie, specjaliści od prahistorii - Michał Kobusiewicz i Lech Krzyżaniak, którzy, pomimo realizowania swej drogi naukowej poza Uniwersytetem, związani z nim byli pracą dydaktyczną oraz prowadzeniem seminariów magisterskich w Instytucie Prahistorii UAM. W środowisku uniwersyteckim w równej mierze orędowali za tym poznańscy historycy sztuki, a szczególnie ówczesny dyrektor Instytutu prof. Szczęsny Skibiński oraz prof. Jerzy Kubczak, kierownik Zakładu Historii Sztuki Starożytnej IHS, i dr hab. Tomasz Wujewski, pracownik tej jednostki. Ideę popierali niezwykle mocno także poznańscy historycy starożytności.

Oficjalną dyskusję, toczoną z czasem z udziałem dziekana prof. Tomasza Jasińskiego na Wydziale Historycznym, nad powołaniem specjalności archeologia śródziemnomorska lub klasyczna, czy raczej powrotem do takiego programu dydaktycznego, który, jak powyżej wykazano, był obecny w Uniwersytecie Poznańskim od samych jego początków, rozpoczęto wiosną 1997 r., rok wcześniej odbywając już spotkania w tej sprawie organizowane przez dyrektora Instytutu Historii Sztuki ${ }^{82}$. Najaktywniejszym graczem bowiem na polu reaktywacji archeologii klasycznej w UAM okazał się jednak Instytut Historii Sztuki, który przyjął stanowisko, iż ma uzasadnione powody do zainteresowania się losami dyscypliny, bezsensownie niegdyś zlikwidowanej na Uniwersytecie. Co więcej, podnoszono, iż po owej likwidacji badania w tym zakresie kontynuowane były właśnie w obrębie Instytutu Historii Sztuki oraz Instytutu Historii; tam powstawały prace naukowe obejmujące starożytność, a poznańscy prahistorycy uniwersyteccy w taką problematykę raczej nie wchodzili. Argumentowano ponadto, bazując na przesłankach historiograficznych, które poświadczają, iż historia sztuki i archeologia klasyczna stanowią w aspekcie genetycznym dyscypliny siostrzane, że można by przekształcić, a w zasadzie rozszerzyć dotychczasową jednostkę dotyczącą badań sztuki antycznej i powołać Zakład Historii Sztuki Starożytnej i Archeologii Klasycznej, który byłby odpowiedzialny za organizację i realizację studiów o nazwie archeologia klasyczna w instytucjonalnych ramach Instytutu Historii Sztuki ${ }^{83}$.

Archeolodzy uniwersyteccy w Poznaniu specjalizujący się głównie w pradziejach i okresie średniowiecza Europy Środkowej, w tym szczególnie ziem polskich oraz $\mathrm{w}$ problematyce związanej z metodologią prahistorii, skupieni w ramach Insty-

\footnotetext{
${ }^{82}$ Większość ważnych wydarzeń zaistniałych w związku z powoływaniem na Wydziale Historycznym UAM, a konkretnie w Instytucie Prahistorii archeologii śródziemnomorskiej, znanych jest autorce z autopsji. Będąc bowiem pracownikiem IP UAM od 1997 r., a uprzednio doktorantką na Wydziale Historycznym, natomiast wcześniej absolwentką zarówno poznańskiej historii sztuki, jak i archeologii, była żywo zainteresowania rozwojem tej specjalności.

${ }^{83}$ Informacje zawarte w obszernym, 8-stronicowym piśmie z wiosny 1997 r. pt. „Stanowisko Instytutu Historii Sztuki w sprawie przywrócenia archeologii klasycznej na Uniwersytecie im. Adama Mickiewicza”, podpisane przez dyrektora Instytutu, prof. Szczęsnego Skibińskiego, kierownika Zakładu Historii Sztuki Starożytnej, prof. Jerzego Kubczaka oraz dr hab. Tomasza Wujewskiego z tegoż Zakładu (dokument w archiwum Instytutu Prahistorii).
} 
tutu Prahistorii, pomimo niepodzielanego w pełni z różnych względów entuzjazmu co do ponownego tworzenia specjalności archeologia klasyczna lub śródziemnomorska w $\mathrm{UAM}^{84}$, wyrazili sprzeciw wobec stanowiska historyków sztuki i uznali, że dyplom z zakresu archeologii, i to jakiejkolwiek specjalności, adepci tej dyscypliny uzyskiwać powinni w placówce prowadzącej studia archeologiczne, czyli w Instytucie Prahistorii, a niezbędną wiedzę z zakresu dyscyplin współdziałających studenci mogą nabywać w ramach współpracy pomiędzy jednostkami uczelni, a szczególnie jednostkami Wydziału Historycznego. Ponadto argumentowano, iż z metodologicznego punktu widzenia archeologia jest jedna, pomimo funkcjonowania w jej obrębie wielu rozmaitych specjalności ${ }^{85}$. W związku z tym Rada Instytutu Prahistorii na posiedzeniu w dniu 10 października 1997 r. podjęła uchwałę o powołaniu w Instytucie nowej specjalności dydaktycznej, którą zamierzano nazwać: Archeologia Basenu Morza Śródziemnego. Z takim wnioskiem wystąpiono do Rady Wydziału Historycznego, a informację o szczegółach tego zamierzenia i formach realizacji przekazano również na ręce ówczesnego rektora, prof. Stefana Jurgi ${ }^{86}$.

Nie rozwiązywało to jednak sporu nad kształtem powoływanej archeologii klasycznej/śródziemnomorskiej, który toczył się na Wydziale Historycznym dalej, aż do wiosny 1999 r. - zasadniczo między historykami sztuki i archeologami, z udziałem historyków starożytności oraz dziekana i członków Rady Wydziału, optujących za wspólnym tworzeniem zintegrowanych studiów przez oba prowadzące spór Instytuty $\mathrm{z}$ włączeniem $\mathrm{w}$ nie historyków. Z czasem uwidoczniła się niestety coraz większa trudność pogodzenia stanowisk reprezentantów zainteresowanych dyscyplin, a wynikała z odmiennych wizji tego, czym nowoczesna archeologia klasyczna (nazwa preferowana przez historyków sztuki) lub śródziemnomorska, będąca szerszym pojęciem (wskazywana przez archeologów), miałaby w XXI w. być. Ponadto pozy-

${ }^{84}$ Sądzę, że brak entuzjazmu co do powoływania specjalności archeologia śródziemnomorska w IP wynikał z kilku powodów, wśród których wymienić można troskę związaną z niedostatkiem kadry naukowo-dydaktycznej wyspecjalizowanej w tym kierunku, jak również brak szerszego zaplecza bibliotecznego i wykopaliskowego oraz świadomość potrzeby wysokich nakładów finansowych na takie studia. Niebagatelny był również fakt, iż Instytut Prahistorii w trakcie swego istnienia wypracował i utrwalił wiodącą pozycję w Polsce na gruncie badań pradziejowych i średniowiecznych oraz teoretycznych, natomiast obawiano się jej osłabienia przez wchodzenie w nową dla jego środowiska problematykę naukową, jak również odciągnięcia przez nią studentów od studiów pradziejowych dotyczących obszaru Europy Środkowej i Polski.

${ }^{85}$ Pismo pt. „Zamierzenia Instytutu Prahistorii UAM w kwestii uruchomienia specjalności ARCHEOLOGIA ŚRÓDZIEMNOMORSKA w ramach studiów archeologicznych” podpisane przez dyrektor Instytutu, prof. Hannę Kóčkę-Krenz oraz zastępcę dyrektora, prof. Dobrochnę Jankowską (dokument w archiwum Instytutu Prahistorii).

${ }^{86}$ Pismo podpisane przez dyrektor Instytutu, prof. Hannę Kóčkę-Krenz z dnia 20.10.1997 r. skierowane do JM Rektora UAM wraz z dołączoną Uchwałą Rady Naukowej Instytutu Prahistorii UAM z dnia 10.10.1997 r. w sprawie powołania specjalności o nazwie ARCHEOLOGIA BASENU MORZA ŚRÓDZIEMNEGO (dokument w archiwum Instytutu Prahistorii). 
tywnemu rozwojowi dyskusji przeszkadzały, bezpodstawne w moim przekonaniu, uprzedzenia, jakie reprezentanci poznańskiej archeologii i historii sztuki wysuwali względem siebie. Archeolodzy bowiem zarzucali historykom sztuki, iż pragną zdominować tworzoną specjalizację ukierunkowaniem wyłącznie na dzieła sztuki i architekturę, które do tego wyrwane będą z kontekstu swego historycznego funkcjonowania, a to uczyni planowaną archeologię minionym antykwaryzmem, niejednokrotnie kojarzonym z rabunkowymi wykopaliskami prowadzonymi na obszarach wielkich cywilizacji starożytnych. Historycy sztuki utrzymywali z kolei, iż wśród archeologów, pomimo deklarowania, że są kompleksową nauką historyczną, wciąż dominuje orientacja pozytywistyczno-materialistyczna, a zatem daleko im do jakiejkolwiek refleksji humanistycznej, będącej już od dawna cechą historii sztuki ${ }^{87}$ itd. Można uznać, że ostateczne rozejście się przedstawicieli obu dyscyplin w trakcie prac nad reaktywowaniem w UAM archeologii śródziemnomorskiej nastąpiło po prostu w wyniku obrony granic dyscyplinarnych i wąskich kompetencji badawczych, które wiążą się z uprawianiem archeologii i historii sztuki, a docelowy, rzeczywiście wspólny program studiów wymagałby większego wyjścia poza nie i współpracy, na co środowisko u schyłku lat 90 . XX w. widocznie jeszcze nie było przygotowane. Nastąpiła obrona suwerenności i specyficznego, wysokiego poziomu „rzemiosła naukowego", jakim cechują się z pewnością obie dyscypliny, twarde trzymanie się metod i zachowań wypracowanych przez pokolenia $\mathrm{z}$ nadzieją, że zostaną w pełnym wymiarze przyjęte przez drugich.

Pomimo takich postaw, na Radzie Wydziału Historycznego w dniu 9 listopada 1998 r. na prośbę Instytutów: Prahistorii, Historii Sztuki oraz Historii postawiony został wniosek, niepoparty jeszcze przedstawieniem szczegółowego programu tych studiów, a jedynie ramowym, o powołanie w Instytucie Prahistorii specjalności archeologia śródziemnomorska. Wniosek został pozytywnie przyjęty przez wszystkich, Rada Wydziału zatem podjęła uchwałę i powołano specjalność, która miała ruszyć wraz z początkiem roku akademickiego 1999/2000, co zresztą nastąpiło ${ }^{88}$. W tym czasie pracowano nad szczegółowym programem dydaktycznym, którego finalnym kształtem zajmowała się głównie ówczesna wicedyrektor Instytutu Prahistorii - czyli placówki mającej studia prowadzić, prof. Dobrochna Jankowska, próbując go konsultować ze wszystkimi zainteresowanymi. Program ten na wniosek Instytutu Prahistorii przekazano do zatwierdzenia Radzie Wydziału Historycznego na posiedzeniu w dniu 8 lutego 1999 r. Jego ostateczny kształt spotkał się jednak z wyraźnym sprzeciwem ze strony historyków sztuki, którzy prosili o dalsze odłożenie sprawy i kontynuowanie prac. Ponieważ jednak w listopadzie roku poprzedniego uchwalono powołanie tych studiów, archeolodzy wnioskowali o dalsze procedowanie sprawy - niemniej po burzliwej dyskusji wśród członków Rady wniosek oddalo-

${ }^{87}$ Uwagi zawarte w pismach przytoczonych w przypisach nr 85 i 86.

${ }^{88}$ Zob. Archiwum UAM, protokoły z Rad Wydziału Historycznego za rok akademicki 1998-99, sygn. 75-997. 
no do rozpatrywania na kolejnych posiedzeniach, optując wciąż za wypracowaniem programu studiów zintegrowanych, w którym oprócz dominującej archeologii przedstawiciele innych zainteresowanych dyscyplin także znajdą swe miejsce ${ }^{89}$. Pomimo takiej decyzji Rady historycy sztuki oznajmili już wówczas, iż odstępują od współtworzenia programu specjalności archeologia śródziemnomorska, który ma być realizowany przez Instytut Prahistorii, a pobudki swego postępowania ogłosili w stosownym piśmie ${ }^{90}$. Sprawa powróciła na posiedzeniu kolejnej Rady Wydziału Historycznego w dniu 8 marca 1999 r., jako wniosek Instytutu Prahistorii UAM o zatwierdzenie programu specjalności archeologia śródziemnomorska realizowanej w ramach studiów archeologicznych w IP. Historycy sztuki podkreślili, iż specjalność ta tworzona jest już samodzielnie tylko przez poznańskich archeologów. Wniosek został przyjęty większością głosów członków Rady ${ }^{91}$.

Wychodząc naprzeciw zapotrzebowaniom środowiska poznańskich uczonych oraz niezmiernie licznych chętnych na studia ówcześnie w Polsce, przy dobrej atmosferze ze strony władz wyższych uczelni do podejmowania tego typu działań, Instytut Prahistorii Uniwersytetu im. Adama Mickiewicza w Poznaniu w 1999 r. poszerzył swą ofertę dydaktyczną oraz obszar planowanych badań o problematykę z zakresu archeologii basenu Morza Śródziemnego - i w październiku tegoż roku rozpoczął kształcenie studentów w obrębie nowej specjalności - archeologii śródziemnomorskiej. Funkcjonowała ona w ramach jednolitych, pięcioletnich studiów magisterskich $w$ ramach jednego kierunku - archeologia, którego adepci po wspólnym pierwszym roku wybierali dalsze kształcenie ukierunkowane albo na Śród-

${ }^{89}$ Zob. Archiwum UAM, protokoły z Rad Wydziału Historycznego za rok akademicki 1998-99, sygn. 75-997.

${ }^{90} \mathrm{~W}$ piśmie z dnia 9 lutego 1999 r., skierowanym do członków Rady Wydziału Historycznego, a złożonym na ręce dziekana, dyrektor Instytutu Historii Sztuki, prof. Szczęsny Skibiński, wyjaśniał ponownie ideę, jaka przyświecała historykom sztuki pragnącym reaktywować w Poznaniu archeologię klasyczną. Powołując się na przedwojenne przepisy mówiące, że „Szkołom akademickim przysługuje prawo wolności nauki i nauczania. Każdy profesor i docent szkoły akademickiej ma prawo podawać i oświetlać z katedry według swego naukowego przekonania i sposobem naukowym wszelkie zagadnienia wchodzące w zakres gałęzi wiedzy, których jest przedstawicielem; tak samo ma zupełną swobodę w wyborze metod wykładów i ćwiczeń" (Ustawa z dn. 13 lipca 1920 r. o szkołach akademickich, Dz.U. nr 72, poz. 494 z 1920 r.), prof. Skibiński argumentował, iż intencją było tworzenie nowoczesnej, ukierunkowanej humanistycznie specjalności śródziemnomorskiej, bez cenzury programu z jakiejkolwiek strony. Według niego archeolodzy natomiast wypracowali program, który ,ułatwi dopasowanie archeologii klasycznej do prokrustowego łoża archeologii pradziejowej”. W konkluzji pisma jednak podkreślił, iż pomimo rozczarowania uważa za lepsze rozpoczęcie odbudowy tej specjalności niż jej zaniechania, tym bardziej że znane mu są wypowiedzi przedstawicieli młodszej generacji poznańskich archeologów, które świadczą, że archeologia śródziemnomorska jest dla nich nadzieją na przyszłość, a nie zagrożeniem - zob. Archiwum UAM, protokoły z Rad Wydziału Historycznego za rok akademicki 1998-99, sygn. 75-997.

${ }^{91}$ Archiwum UAM, protokoły z Rad Wydziału Historycznego za rok akademicki 1998-99, sygn. 75-997. 
ziemnomorze, albo na pradzieje i średniowiecze Europy Środkowej. Przyjęty, niezmiernie ambitny moim zdaniem i bardzo rozbudowany program studiów specjalności śródziemnomorskiej w Poznaniu obejmował konieczność zaliczenia następujących przedmiotów kierunkowych: archeologia Egiptu, archeologia cywilizacji bliskowschodniej, archeologia cywilizacji anatolijsko-egejskiej, archeologia Grecji, Rzymu, prowincji rzymskich oraz wczesnochrześcijańska. Ponadto wspomnianym przedmiotom kursowym towarzyszyć miały równocześnie odrębne zajęcia z zakresu historii sztuki starożytnej wymienionych regionów, a także historii i języków starożytnych, i co więcej: również wszystkie minima programowe specjalności pradziejowej i średniowiecznej, wykładane w formie okrojonej, ale obejmujące cały program w układzie chronologicznym - od paleolitu aż po średniowiecze ${ }^{92}$. Dosyć szybko zaczęto w ów szeroko zakrojony program wprowadzać korekty, polegające najpierw na włączeniu wyodrębnionych zajęć z zakresu historii sztuki starożytnej w kursy archeologii poszczególnych regionów, a z czasem zaczęto wycofywać się też z obligatoryjnego zaliczania pełnego kursu archeologii pradziejowej i średniowiecznej przez studentów specjalności śródziemnomorskiej.

Przesłanki ku takiemu podejściu były następujące. Przyjmując na siebie prowadzenie nowych studiów, archeolodzy z Instytutu Prahistorii uzgodnili już na wstępie dalsze zasady, według których miało się to odbywać. Przede wszystkim postanowiono budować tę specjalność stopniowo, równolegle z odpowiednim przygotowaniem oraz rozwojem kadry naukowo-dydaktycznej, rozbudową biblioteki i poszerzeniem bazy lokalowej Instytutu. Ponadto wdrożenie specjalności miało odbywać się w ramach istniejących już struktur organizacyjnych Instytutu, a rozbudowę o nowy zakład przewidywano ewentualnie po docelowym przejęciu Ekspedycji Novae oraz zapewnieniu jej odpowiedniego finansowania ${ }^{93}$. W pierwszych pięciu latach prowadzenia specjalności, tj. aż do 2004 r., studenci archeologii śródziemnomorskiej w Poznaniu, oprócz wymienionych powyżej zajęć kursowych dotyczących archeologii i sztuki cywilizacji obszarów śródziemnomorskich, zaliczali jednak równolegle nieco pomniejszony godzinowo, ale pełny kurs archeologii pradziejowej i średniowiecznej. Wynikało to głównie z dbałości o zachowanie wysokiego poziomu wykształcenia w IP w obliczu niedostatku kadry wyspecjalizowanej w problematyce śródziemnomorskiej, ale powodowało, że studia te były przeciążone merytorycznie oraz niesymetryczne względem prowadzonej równolegle specjalności pradziejowej i średniowiecznej. Ostatecznie wraz z rozwojem sytuacji i pozyska-

\footnotetext{
${ }^{92}$ Archiwum UAM, protokoły z Rad Wydziału Historycznego za rok akademicki 1998-99, sygn. 75-997.

${ }^{93}$ Pismo podpisane przez dyrektor Instytutu, prof. Hannę Kóčkę-Krenz, z dnia 20.10.1997 r. skierowane do JM Rektora UAM wraz z dołączoną Uchwałą Rady Naukowej Instytutu Prahistorii UAM z dnia 10.10.1997 r. w sprawie powołania specjalności o nazwie ARCHEOLOGIA BASENU MORZA ŚRÓDZIEMNEGO (dokument w archiwum Instytutu Prahistorii).
} 
niem etatów dla specjalistów w 2004 r. rozdzielono oba programy, zachowując jeden nabór na kierunek archeologia w Poznaniu i pozostawiając wspólny, studiowany łącznie pierwszy semestr dla obu specjalności. Co więcej, przemianowano wówczas specjalność śródziemnomorską na Archeologię Orientalną i Antyczną, pragnąc się wyróżnić wśród placówek prowadzących studia w zakresie archeologii śródziemnomorskiej w Polsce. Warto zwrócić także uwagę, iż od samych początków powołania nowej specjalności w IP przyświecała środowisku poznańskiemu chęć wypracowywania własnej specyfiki badawczej, m.in. ukierunkowanej na problematykę powiązań między Europą Środkową a Śródziemnomorzem czy na tzw. okresy formatywne cywilizacji basenu Morza Śródziemnego. Wreszcie w 2008 r. nastąpiły zmiany organizacyjne $\mathrm{w}$ jednostce, aczkolwiek wskutek braku możliwości porozumienia z kolei wewnątrz Instytutu, zamiast jednego zakładu powołano 1 października dwie pracownie: Pracownię Archeologii Cywilizacji Śródziemnomorskich oraz Pracownię Archeologii Śródziemnomorskiej Epoki Brązu. W tym czasie wygaszeniu uległy jednolite studia magisterskie, a wprowadzono studia dwustopniowe, na których, wciąż w ramach jednego kierunku studiów w zakresie archeologii w Poznaniu, prowadzona jest do dzisiaj na obu poziomach specjalizacja archeologia orientalna i antyczna ${ }^{94}$, a jej absolwenci otrzymują dyplomy z zaznaczeniem tego faktu. Rozwija się ona powoli, aczkolwiek systematycznie, i sądzę, że z powodzeniem - głównie dzięki zaangażowaniu pozyskiwanych specjalistów z ośrodka warszawskiego oraz własnym potencjałem kadrowym Instytutu.

Na koniec, odnosząc się jeszcze do wspomnianej dyskusji na temat pojmowania czy definiowania archeologii klasycznej, pragnę dodać, że dzisiejsza archeologia klasyczna czy też inaczej, antyczna, stara się być dyscypliną w pełni nowoczesną i otwartą, która już dawno odeszła od minionego antykwaryzmu i zabytkoznawstwa, nastawionego jedynie na dzieła sztuki, i to często rozpatrywane jako świat autonomiczny, oderwany od jakiegokolwiek kontekstu wytworzenia i funkcjonowania, jak również od zapatrzenia $\mathrm{w}$ dane filologiczne. Utraciła, co prawda, niegdysiejszą uprzywilejowaną pozycję, ale jako jedna z bardzo wielu, przy czym równoprawna gałąź archeologii, włącza w zakres swych zainteresowań to samo co inne. Są to mianowicie wszystkie pozostałości materialne po starożytnych społecznościach, jak również środowisko naturalne i badania nad przestrzenią oraz krajobrazem, nad procesami urbanizacji i miejscami centralnymi, nad osadami i domostwem, kultem oraz rytuałem, tożsamością i wiele innych zagadnień ${ }^{95}$. Nie sądzę jednak, że przy dzisiejszym krytycznym spojrzeniu na minione badania nastawione na swoiście

\footnotetext{
${ }^{94}$ Zob. strona domowa Instytutu Prahistorii UAM i dział Edukacja - http://archeo.amu.edu.pl [dostęp: lipiec 2013 r.].

${ }^{95}$ Obszernie na ten temat wypowiedziałam się na łamach FPP w tekście zatytułowanym Archeologia klasyczna w poszukiwaniu swej tożsamości. Między przesztością, teraźniejszościq a historia sztuki (Bugaj 2011).
} 
rozpatrywane dzieła sztuki powinna się odcinać od tej tradycji, co byłoby moim zdaniem wyjątkowym jej zubożeniem i zaprzepaszczeniem bardzo cennych dokonań. Dobrze pojmowana tradycja to jest jej aktualizacja. Ostatecznie to, jakie badania będą podejmowane oraz w jaki sposób, zależy od wiedzy i kompetencji badaczy, ich otwartości na nowe inspiracje oraz od krytycznego spojrzenia na dokonania dotychczasowe, co zawsze poszerza horyzonty. Mam nadzieję, że nisza na taką archeologię na Uniwersytecie im. Adama Mickiewicza w Poznaniu zawsze będzie się znajdować.

\section{BILBIOGRAFIA}

\section{Źródła}

Uniwersytet Poznański w pierwszych latach swego istnienia (1919, 1919-20, 1920-21, 1921-22, 1922-23), red. A. Wrzosek, Poznań 1924.

Kroniki Uniwersytetu Poznańskiego...

Kroniki Uniwersytetu im. Adama Mickiewicza...

Uniwersytet Poznański. Sktad Uniwersytetu...

Uniwersytet Poznański. Spisy Wykładów...

Uniwersytet Poznański. Skład Uniwersytetu i spisy wykładów...

Akta Mieczysława Sabina Ruxer w Archiwum UAM (sygn. 15-611-26; 82-385; 153-123; 191).

Akta Jerzy Kubczak w Archiwum UAM (sygn. 296; 467).

Protokoły z Rad Wydziału Historycznego UAM za rok akademicki 1998-99 w Archiwum UAM (sygn. 75-997).

Dokumenty z Archiwum Instytutu Prahistorii UAM.

\section{Opracowania}

Abramowicz A.

1987 Dzieje zainteresowań starożytniczych $w$ Polsce, cz. 2: Czasy stanistawowskie i ich pokłosie, Wrocław.

1991 Historia archeologii polskiej. XIX i XX wiek, Warszawa-Łódź.

$1992 \quad$ Historia archeologii polskiej. Początki, Łódź.

Biernacki A., Szymkiewicz J.

2003 Novae - antyczne miasto. Zabytki ze zbiorów Muzeum Historycznego w Swisztowie (własność Republiki Butgarii), katalog wystawy, Poznań.

Bugaj E.

2011 Archeologia klasyczna w poszukiwaniu swej tożsamości. Między przeszłością, teraźniejszością a historią sztuki, Folia Praehistorica Posnaniensia 16, s. 255-279.

Bulanda E.

1947 Archeologia klasyczna, Archeologia 1947, 1, s. 7-42.

Czubiński A.

1972 Dzieje Uniwersytetu Poznańskiego w latach 1918-1939 [w:] Dzieje Uniwersytetu im. Adama Mickiewicza 1919-1969, red. Z. Grot, Poznań, s. 59-302. 
Dyson S. L.,

2006 In Pursuit of Ancient Pasts. A History of Classical Archaeology in the Nineteenth and Twentieth Centuries, New Haven-London.

Gąsiorowski S. J.

1959 Mieczysława Sabina Ruxer (10 X 1891 - 5 IV 1957) i jej działalność naukowa, Archeologia 1957 8/2, s. 499-507.

Grot Z.

1972 Czterysta lat walki o Uniwersytet w Poznaniu [w:] Dzieje Uniwersytetu im. Adama Mickiewicza 1919-1969, red. Z. Grot, Poznań, s. 9-58.

Kaczmarek J.E.

1996 Organizacja badań i ochrony zabytków archeologicznych w Poznaniu (1720-1958), Biblioteka Fontes Archaeologici Posnanienses 8, Poznań.

Kubczak J.

1957 Pamięci Mieczysławy Ruxer, Z Otchtani Wieków 1957, 23/4, s. 177-180.

1995 Prof. dr Stefan Parnicki-Pudełko (10 VII 1914 - 16 IV 1994), Meander 50/5-6, s. 289-294.

1998 Mieczysława S. Ruxer (1891-1957) [w:] Archeologia śródziemnomorska w Uniwersytecie Jagiellońskim 1897-1997, red. J. Śliwa, Kraków, s. 49-53.

Liman K.

1992 Ruxerówna Mieczysława Sabina (1891-1957), Polski słownik biograficzny 33 (19911992), s. 266-267.

Łuczak C.

1999 Uniwersytet Poznański w latach drugiej wojny światowej [w:] Alma Mater Posnaniensis. W 80. rocznicę utworzenia Uniwersytetu w Poznaniu, red. P. Hauser, T. Jasiński, J. Topolski, Poznań, s. 171-207.

Łukomski G.

2004a Komisja Organizacyjna Uniwersytetu Polskiego w Poznaniu 1818-1919 [w:] W hotdzie naszym Antenatom. 85 lat Uniwersytetu im. Adama Mickiewicza, red. J. Laskowski, G. Łukomski, Poznań, s. 30-48.

2004b Otwarcie Wszechnicy Piastowskiej [w:] W hotdzie naszym Antenatom. 85 lat Uniwersytetu im. Adama Mickiewicza, red. J. Laskowski, G. Łukomski, Poznań, s. 49-59.

Majewski K.

1952 Archeologia klasyczna w Polsce. Dorobek i plan, Archeologia 1949, 3, s. 233-265.

1965 Dwadzieścia lat polskich badań w zakresie archeologii klasycznej, Archeologia 1964, 15, s. 310-312.

Parnicki-Pudełko S.

1984 Kazimierz Majewski (1903-1981) jako badacz i organizator badań nad rzymską kulturą w Bułgarii, Balcanica Posnaniensia. Acta et studia 1, s. 13-20.

Press L.

1995 Stefan Parnicki-Pudełko (10 VII 1914 - 16 IV 1994), Archeologia 1994, 45, s. 121-125.

Śliwa J.

2007 Profesor Jerzy Kubczak (1928-1999). Wspomnienie o przyjacielu [w:] Eurazja i Antyk, red. A. Bednarczuk, E. Bugaj, W. Rządek, Poznań, s. 17-21.

Śliwa J. red.

1998 Archeologia śródziemnomorska w Uniwersytecie Jagiellońskim 1897-1997, Kraków.

Wujewski T.

2000 Jerzy Kubczak (2 III 1928 - 9 III 1999), Archeologia 1999, 50, s. 109-112.

Żuchowski T.J.

2007 Profesor Jerzy Kubczak a dydaktyka uniwersytecka [w:] Eurazja i Antyk, red. A. Bednarczuk, E. Bugaj, W. Rządek, Poznań, s. 23-27. 


\title{
CLASSICAL ARCHAEOLOGY AT THE UNIVERSITY IN POZNAŃ AND CIRCUMSTANCES OF ITS ESTABLISHING
}

\author{
S u m m a r y
}

Classical Archaeology as a subject was established at the University of Poznań with the creation of the University itself in 1919, but as a key date in its development should be seen 30th April, 1923, when Mieczysława Sabina Ruxer, PhD, teaching the subject, took care of the Classical Archaeology Seminar. She came to Poznań from Kraków and was appointed an assistant professor responsible for development of Classical Archaeology as an academic subject, both as research and teaching area. She also made and attempt to create an independent Department of Classical Archaeology.

Before World War II the Seminar functioned as a secondary course, and the Department of Classical Archaeology as an ancillary part of the Faculty of Humanities. Due to the nature of this secondary course there were no graduates in Classical Archaeology, as the seminar was chosen by students who studied other disciplines as their main. However, Ruxer taught numerous classes of extremely large range of problems, which were over the years of her work systematically improved. According to the archives, in the 1930s, there were efforts made to prepare the curriculum for the study of Classical Archaeology as a main subject to be completed with a degree. It had been provisionally accepted by the University, and after approval of Ruxer's habilitation, which took place in 1937 at the Jagiellonian University, the change of the status of Classical Archaeology Seminar from auxiliary to regular appeared - but unfortunately the plan was disturbed by the war.

After World War II, from the very beginning, when teaching at the University of Poznan was re-established, the Classical Archaeology Seminar functioned, led by Ruxer. Unfortunately, the Chair and the Department in the difficult post-war conditions had to be painstakingly re-organized as the entire pre-war furnishing and collections were destroyed or stolen. Moreover, in post-war years attempts were made to rebuild academic life in Poland in the new political and ideological situation, according to arbitrarily imposed rules, often subordinated to Soviet science. Reorganisation, unification and centralisation of scientific institutions took place - illustrated by, among others, forced integration of Prehistoric and Classical Archaeology (later Mediterranean), and Ethnography in the purpose of joint research on material culture. This was due to the introduction of materialist philosophy in the field of scientific research as the current dogma, particularly inconvenient on the ground of the humanities.

Such changes took place also in the Faculty of Humanities at the University of Poznań. Professor Ruxer worked as the head of the Chair and Department of Classical Archaeology till 1952, which she had been appointed to in 1949. Moreover, a new person appeared in the Department, a full-time assistant - Jerzy Kubczak. However, in 1952 the Department was renamed since then known as the Department of Mediterranean Archaeology and was incorporated into the Department of History of Art. Ruxer was deprived of her functions. Finally, in the academic year 1955/1956 the Department of Mediterranean Archaeology was suspended. Moreover, in 1957 the death snatched Professor Mieczysława Sabina Ruxer from the Faculty of Philosophy and History. Among the extensive scientific interests it is worth emphasising that the main area of her studies was ancient jewellery and she produced a monograph on the Greek necklaces. 
After the so-called "Thaw", at the end of 1957 a classical archaeologist Stefan ParnickiPudełko, PhD from Wroclaw, working in the Department of Ancient Archaeology at the Institute of History of Material Culture at the Academy of Sciences in Warsaw, was invited to Poznań. After the appointment to an assistant professor, Parnicki-Pudełko became a head of the reactivated Chair of Mediterranean Archaeology at the Faculty of Philosophy and History, with the effect from 1st October 1958. Also Jerzy Kubczak, who in the meantime worked in the National Museum in Poznan, returned to the Chair. The scientific contributions of the Chair, which should be considered a true continuation of Professor Ruxer's idea, have related primarily to studies on the ancient architecture and pottery, as well as the culture of the ancient colonies on the northern shores of the Black Sea. In this organizational form the Chair of Mediterranean Archaeology had functioned at Adam Mickiewicz University for the next ten years - until 1969, when it was closed. After that, Professor Parnicki-Pudełko took the position of the head of the Department of Ancient History, and Kubczak PhD a job at the Institute of History of Art. Interestingly, only then Poznań research centre really got involved in excavations in the area of Mediterranean civilisation, as in 1970 an independent University Archaeological Expedition of Adam Mickiewicz University in Poznań began excavations in the Roman legion camp in Novae (in ancient Moesia Inferior), and has been operating by today.

When it comes to scientific achievements, it should be emphasized that Professor ParnickiPudełko was primarily an outstanding expert in ancient construction, leaving as his legacy to next generations, among numerous other works, a monograph on Greek architecture. Professor Kubczak, on the other hand, focused his attention, like Ruxer, whose research he continued, on ancient jewellery, publishing a monographic study of Greek necklaces in the Hellenistic and Roman periods. A key topic of his study, however, were issues concerning Scythian culture, which was reflected in the monograph about the barrows of Scythian aristocracy.

In the meantime, interest of scholars from Poznań, both those associated with the University, and those from the outside of it, in archaeological research in the Mediterranean not only did not decrease, but increased immensely. In addition, after the historic turn in Poland of 1989 and regaining sovereignty it became possible to resurrect departments and disciplines taught in the past, and to broaden significantly the educational offer and the fields of scientific research. In such an atmosphere the efforts were made in the 1990s to establish (reactivate) Mediterranean (or Classical) Archaeology at Adam Mickiewicz University.

After long debates concerning the nature of the discipline to be reactivated in Poznań, mainly between the employees of the Institutes of History of Art and Prehistory at Adam Mickiewicz University, the Council of the Faculty of History decided with a resolution of 9th November 1998, to appoint a specialty of Mediterranean Archaeology at the Institute of Prehistory, starting from the academic year 1999/2000. It has been a part of Archaeology taught by the Institute of Prehistory at Adam Mickiewicz University, as a main discipline, developing slowly but successfully under the name of Oriental and Classical Archaeology, accepted in 2004.

Translated by Lucyna Leśniak 